\title{
EVALUATION OF ALTERNATIVE FILTER MEDIA FOR THE ROTARY MICROFILTER
}

\author{
Michael R. Poirier \\ David T. Herman \\ Ramesh Bhave (ORNL)
}

September 2011 contract number DE-AC09-08SR22470. 
SRNL-STI-2011-00522

Revision 0

\section{DISCLAIMER}

This work was prepared under an agreement with and funded by the U.S. Government. Neither the U.S. Government or its employees, nor any of its contractors, subcontractors or their employees, makes any express or implied:

1. warranty or assumes any legal liability for the accuracy, completeness, or for the use or results of such use of any information, product, or process disclosed; or

2. representation that such use or results of such use would not infringe privately owned rights; or

3. endorsement or recommendation of any specifically identified commercial product, process, or service.

Any views and opinions of authors expressed in this work do not necessarily state or reflect those of the United States Government, or its contractors, or subcontractors.

Printed in the United States of America

Prepared for U.S. Department of Energy 
Keywords: Filtration, Sludge, Rotary Microfilter

Retention: Permanent

\section{EVALUATION OF ALTERNATIVE FILTER MEDIA FOR THE ROTARY MICROFILTER}

Michael R. Poirier

David T. Herman

Ramesh Bhave (ORNL)

September 2011

Savannah River National Laboratory Savannah River Nuclear Solutions, LLC Aiken, SC 29808

Prepared for the U.S. Department of Energy under

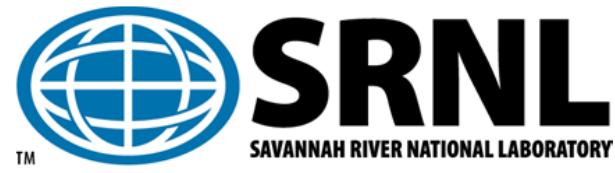
contract number DE-AC09-08SR22470. 


\section{REVIEWS AND APPROVALS}

\section{AUTHORS:}

M. R. Poirier, SRNL, Advanced Characterization \& Processing

Date

D. T. Herman, SRNL, Advanced Characterization \& Processing

Date

R. Bhave, ORNL, Inorganic Membrane Group

Date

TECHNICAL REVIEW:

C. A. Nash, SRNL, Advanced Characterization \& Processing

Date

APPROVAL:

F. M. Pennebaker, Manager, SRNL, Advanced Characterization \& Processing

Date

S. L. Marra, Manager, SRNL, E\&CPT Research Programs

Date 


\section{EXECUTIVE SUMMARY}

The Savannah River Site (SRS) is currently developing and testing several processes to treat high level radioactive liquid waste. Each of these processes has a solid-liquid separation process that limits its throughput. Savannah River National Laboratory (SRNL) researchers identified and tested the rotary microfilter as a technology to increase solid-liquid separation throughput. The authors believe the rotary microfilter throughput can be improved by using a better filter membrane. Previous testing showed that asymmetric filters composed of a ceramic membrane on top of a stainless steel support produced higher filter flux than $100 \%$ stainless steel symmetric filters in crossflow filter tests. SRNL and Oak Ridge National Laboratory (ORNL) are working together to develop asymmetric ceramic - stainless steel composite filters and asymmetric 100\% stainless steel filters to improve the throughput of the rotary microfilter.

The ORNL Inorganic Membrane Group fabricated samples of alternative filter membranes. In addition, SRNL obtained samples of filter membranes from Pall, Porvair, and SpinTek. They tested these samples in a static test cell with feed slurries containing monosodium titanate (MST) and simulated sludge.

The conclusions from this analysis follow.

- The Porvair Sinterflo 3 filter media produced 15-20\% higher flux than the baseline Pall PMM050 membrane.

- The ORNL SVB6-1B membrane produced the same and up to 20\% higher flux than the Pall PMM050 membrane and comparable flux to the Porvair membrane with simulated sludge feeds.

\section{Recommendations:}

- Because of the limited testing and the small difference in filter flux between the PMM050, Porvair Sinterflo 3, and the ORNL SVB6-1B, the authors recommend additional bench-scale testing be performed to select the best filter media prior to fabricating and testing full-scale filter disks.

- This testing would include longer run times, multiple filtering and cleaning cycles, and additional solids loadings. Additionally, these tests would include measuring turbidity rather than visual observations to assess filtrate quality. 


\section{TABLE OF CONTENTS}

LIST OF ABBREVIATIONS ....................................................................................................... vii

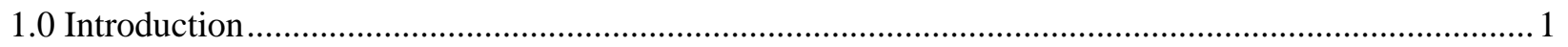

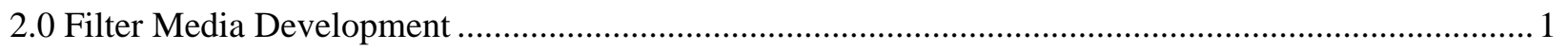

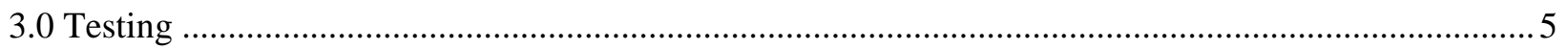

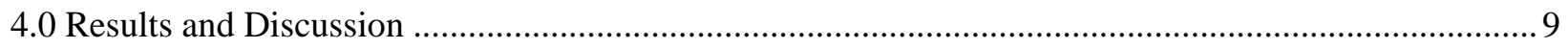

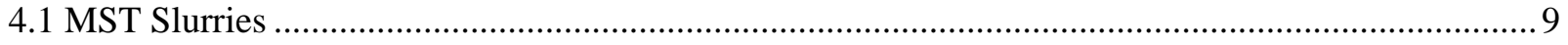

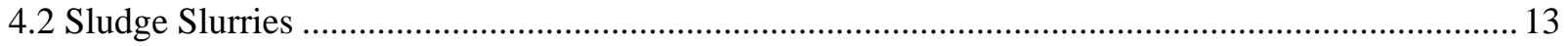

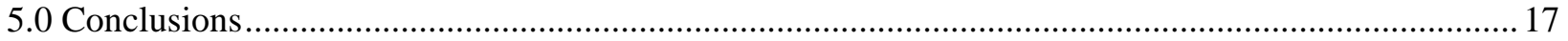

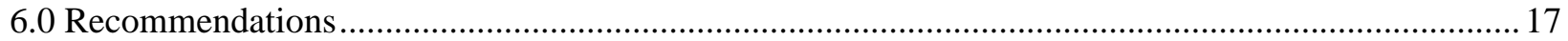

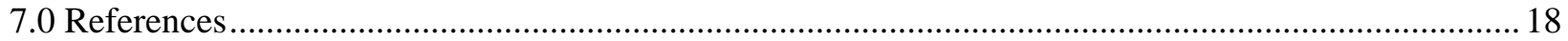




\section{LIST OF ABBREVIATIONS}

$\begin{array}{ll}\text { DOE } & \text { Department of Energy } \\ \text { INEEL } & \text { Idaho National Energy and Environmental Laboratory } \\ \text { ISDP } & \text { Integrated Salt Disposition Process } \\ \text { MST } & \text { Monosodium Titanate } \\ \text { ORNL } & \text { Oak Ridge National Laboratory } \\ \text { SCIX } & \text { Small Column Ion Exchange } \\ \text { SRNL } & \text { Savannah River National Laboratory } \\ \text { SRS } & \text { Savannah River Site } \\ \text { SS } & \text { Stainless Steel } \\ \text { SWPF } & \text { Salt Waste Processing Facility } \\ \text { TMP } & \text { Transmembrane Pressure }\end{array}$


SRNL-STI-2011-00522

Revision 0

\subsection{Introduction}

SRS is currently developing and testing several processes to treat high level radioactive liquid waste. These processes include the Integrated Salt Disposition Process (ISDP), the Salt Waste Processing Facility (SWPF), and the Small Column Ion Exchange Process (SCIX). Each of these processes has a solid-liquid separation process that limits its throughput.

SRNL researchers identified and tested the rotary microfilter as a technology to increase solid-liquid separation throughput. ${ }^{1,2,3}$ The testing showed significant improvement in filter flux with the rotary microfilter over the baseline crossflow filter (i.e., $2.5-6.5 \mathrm{X}$ during scoping tests, as much as $10 \mathrm{X}$ in actual waste tests, and approximately $3 \mathrm{X}$ in pilot-scale tests).

SRNL received funding from DOE EM-21, and subsequently DOE EM-31 to develop the rotary microfilter for high level radioactive service. The work has included upgrading the rotary microfilter for radioactive service, testing with simulated SRS waste streams, and testing it with simulated Hanford waste streams. ${ }^{4,5}$

While the filtration rate is better than that obtained during testing of crossflow filters, the authors believe the rotary microfilter throughput can be improved by using a better filter membrane. The rotary microfilter membrane is made of stainless steel (Pall PMM050). Previous testing, funded by DOE EM-21, showed that asymmetric filters composed of a ceramic membrane on top of a stainless steel support produced higher filter flux than $100 \%$ stainless steel symmetric filters in crossflow filter tests. ${ }^{6}$ In that testing, the Pall Accusep and Graver filters produced 13 - 21\% larger filter flux than the baseline $0.1 \mu \mathrm{m}$ Mott filter. While the improvement in flux is not as dramatic as the improvement of the rotary filter over a crossflow filter, a $13-21 \%$ increase could reduce the lifetime of a 30 year process by $4-6$ years, with significant cost savings.

Subsequent rotary filter testing showed the Pall PMM050 stainless steel filter membrane produced higher flux than the Mott filter media in bench-scale and pilot-scale testing. ${ }^{7}$ The Accusep and Graver filter media were not evaluated in that testing, because they are not available as flat sheets.

The Accusep filter was developed at ORNL and licensed to Pall Corporation. This filter has a stainless steel support structure with a zirconium oxide ceramic membrane. The pore size is $0.1 \mu \mathrm{m}$ absolute.

The Graver filter has a stainless steel support structure with a titanium dioxide ceramic membrane. The pore size is $0.07 \mu \mathrm{m}$ absolute.

SRNL and ORNL are working together to develop filter media similar to the Accusep and Graver media, and to test them in a bench-scale filtration apparatus to attempt to improve the throughput of the rotary microfilter. This report describes the effort.

\subsection{Filter Media Development}

ORNL composite membranes were fabricated on highly permeable and uniform support structures composed of stainless steel (SS) 316B material with mean particle size of $10 \mu \mathrm{m}$ obtained from Ametek Corporation. The porous support was fabricated using tape casting. The green support material was air dried, and samples were trimmed to a size slightly larger than the desired size ( 3 inch $\mathrm{x} 4.25$ inch). The samples were then sintered at high temperature $\left(1050-1080^{\circ} \mathrm{C}\right)$ under an argon/hydrogen atmosphere. 
A number of characterization measurements were performed on support and membrane samples which included bubble point, gas permeance, liquid permeability and pore size distribution. Table 1 shows the results of these measurements on some of the representative samples. For the porous support structure, bubble point measurements were used to determine the mean pore size. Due to the relatively large pore size, perm porometry measurements on support samples were not performed. The support structure showed a very narrow pore size distribution as the pressure at which bubbling was observed on the entire sample was within a few tenths of a psi (2.2 -2.5 psi with isopropanol). This bubble point pressure corresponds to a pore size of about $4 \mu \mathrm{m}$. The support thickness ranged from 32-35 mil. Some of the porous supports with somewhat higher thickness ( $\sim 50 \mathrm{mil}$ ) were also fabricated to determine the optimal support thickness to minimize deformation during high temperature sintering.

Table 1. Composite Membrane Characteristics

\begin{tabular}{|c|c|c|c|c|c|}
\hline Sample & $\begin{array}{c}\text { Thickness, } \\
\text { mil }\end{array}$ & $\begin{array}{l}\text { Bubble point } \\
\text { range (psi)* }\end{array}$ & $\begin{array}{l}\text { Mean pore } \\
\text { size }(\mu \mathrm{m})\end{array}$ & $\begin{array}{c}\text { Gas } \\
\text { Permeance } \\
\left(\mathrm{cm}^{3} / \mathrm{cm}^{2}-\right. \\
\text { min-cm Hg) }\end{array}$ & $\begin{array}{c}\text { Liquid } \\
\text { Permeability } \\
\left(\mathrm{GPM} / \mathrm{ft}^{2} \text { at }\right. \\
20-40 \mathrm{psi})\end{array}$ \\
\hline Support & $32-35$ & $2.2-2.5$ & 4.5 & 13.5 & $9.6 @ 20$ psi \\
\hline $\begin{array}{c}\text { Composite } \\
\text { SVB3-13 }\end{array}$ & $41-44$ & $3.5-5.5$ & 1.0 & 6.1 & 10.9@30 psi \\
\hline $\begin{array}{c}\text { Composite } \\
\text { SVB5-6 }\end{array}$ & $48-52$ & $4.5-6$ & 0.8 & 4.5 & $7.8 @ 30$ psi \\
\hline SVB6-1B & $\sim 50$ & $6.5-12.5$ & 0.5 & 1.3 & $5.1 @ 40$ psi \\
\hline
\end{tabular}

* denotes pressure range from observation of first bubble to uniform bubbling along the entire sample using pure isopropanol

The membrane layers were fabricated on top of the highly porous support structure using a variety of materials. It was observed that one or two layers of finer grade 316 SS material with mean particle size of about $5 \mu \mathrm{m}$ (Atmix5) resulted in a composite membrane with pore size of about 1.0 -1.2 $\mu \mathrm{m}$. An example of such as a membrane is shown in Figure 1. In the figure, the $x$-axis shows the pore size, and the $y$-axis shows the cumulative percentage of pores that are larger than that pore size (based on the percentage of flow passing through pores of a given size). Figure 1 shows the maximum pore size is $1.8 \mu \mathrm{m}$ and the minimum pore size is $1 \mu \mathrm{m}$.

The goal of the project was to develop membrane structures with pore size in the range of $0.1-0.5 \mu \mathrm{m}$ to minimize and/or to prevent pore and depth fouling while maintaining high water permeability to achieve higher flux through surface filtration in the rotary microfilter configuration. Previous work performed by SRNL strongly suggested that membranes with the above range of pore diameters and composed of ceramic materials (zirconia, titania) outperformed nominal 0.1 and $0.5 \mu \mathrm{m}$ homogeneous stainless steel filter media. This is partly due to the fact that particles in highly radioactive sludge are believed to contain fines with particles substantially $<1 \mu \mathrm{m}$ and some even as low as $0.1 \mu \mathrm{m}{ }^{8}$

This led us to search for materials with the finest stainless steel particles available on the market. We used Atmix3 and Atmix5 with mean particle size of $\sim 3 \mu \mathrm{m}$ and $\sim 5 \mu \mathrm{m}$ to fabricate thin layers (1-3 mil) on porous composite supports. These are produced by Epson Atmix Corporation. Additionally, membrane layers were fabricated incorporating aluminum titanate and titanium dioxide with particle size 25-100 nm (0.025-0.1 $\mu \mathrm{m})$. Membrane layers with composite mix of Atmix3 and aluminum titanate were successfully fabricated. During the fabrication of the filter media samples containing titania colloidal sols and particle suspensions, cracking of the ceramic membrane layers occurred. Researchers are working to 
resolve the issues causing the cracking. If these issues can be resolved, ceramic membranes with smaller pore size $(\sim 0.2 \mu \mathrm{m})$ could be fabricated.

\section{SVB3-13}

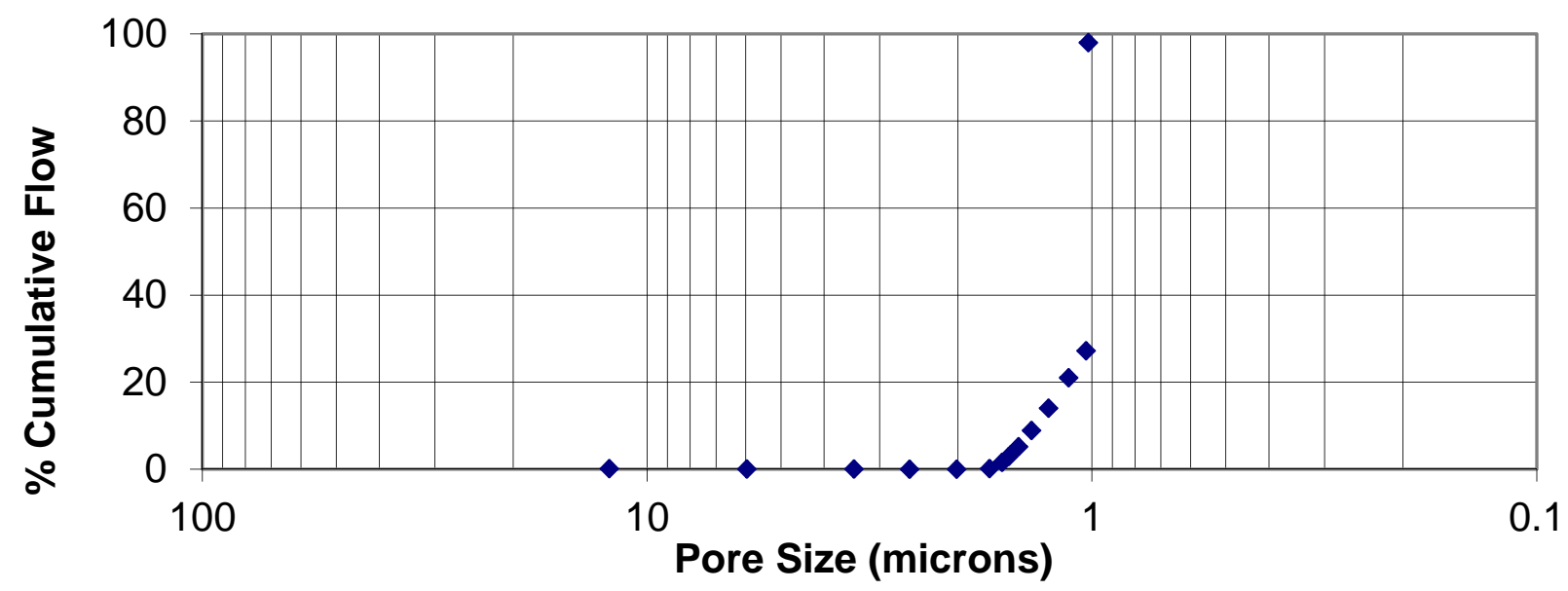

Figure 1. Pore Size Distribution of $1 \mu \mathrm{m}$ SVB3-13 Composite Membrane

Figure 2 shows an example of a $0.8 \mu \mathrm{m}$ membrane (SVB5-6) with a narrow and uniform pore size distribution. This membrane has a top layer composed of Atmix5-aluminum titanate composite. This membrane showed promising results when tested with 1 wt. \% MST.

\section{SVB5-6}

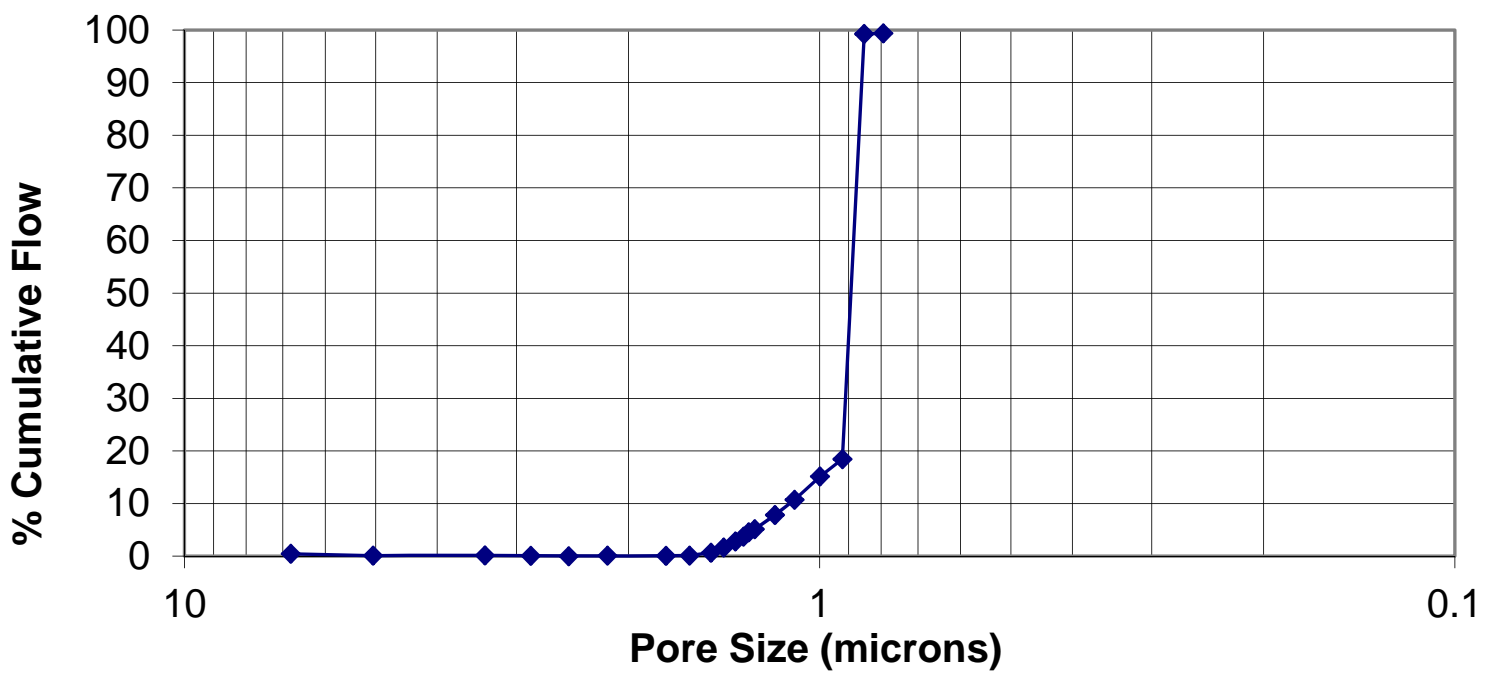

Figure 2. Pore Size Distribution of 0.8 $\mu \mathrm{m}$ SVB5-6 Composite Membrane

Figure 3 shows the example of a $0.5 \mu \mathrm{m}$ membrane (SVB6-1B) with a narrow and uniform pore size distribution. This membrane is composed of up to three layers of Atmix3 on porous support. Each layer is 1-3 mil thick and provides high permeability. 


\section{SVB6-1B}

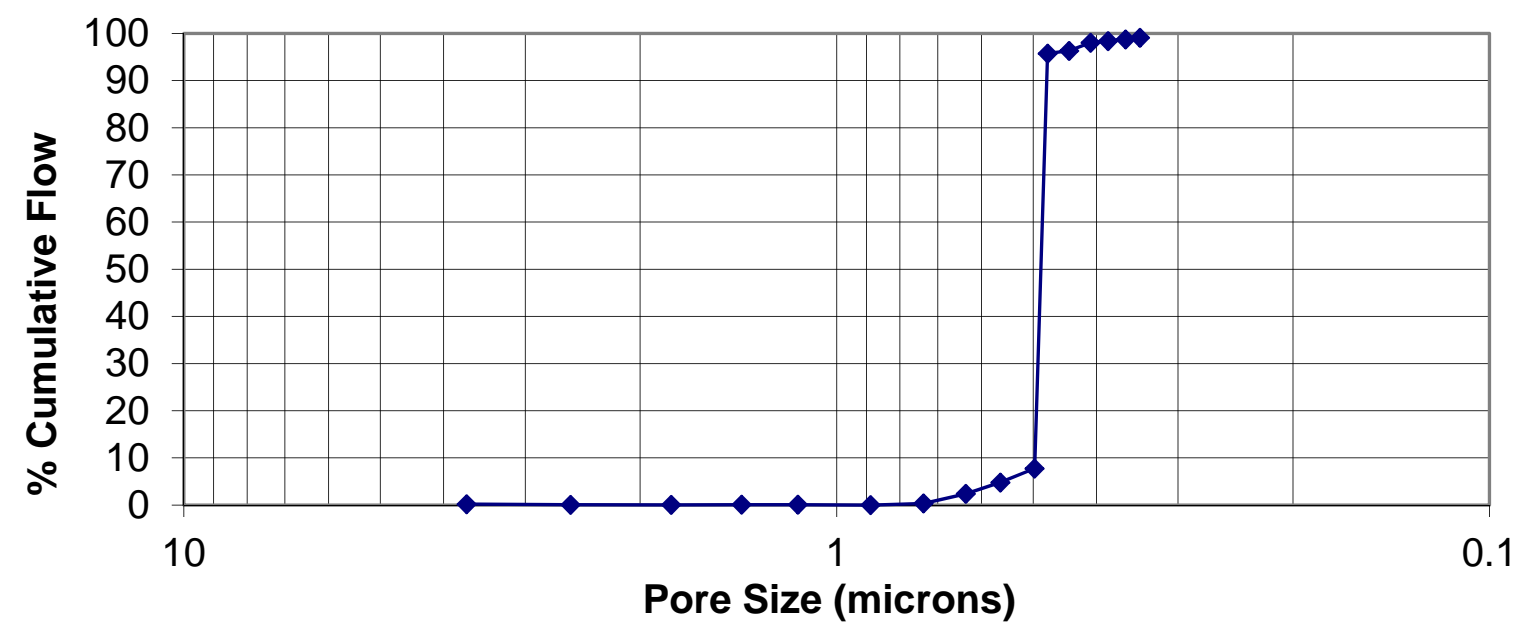

Figure 3. Pore Size Distribution of $0.5 \mu \mathrm{m}$ Composite Membrane

In addition to the membranes described, several commercially available membranes were evaluated. Table 2 shows the media developed and obtained for testing. In Table 2, the pore size is described as absolute or nominal. Absolute pore sizes were determined by challenging the filter with uniformly sized particles, while nominal pore sizes were determined from bubble point measurements.

Table 2. Filter Media Developed and Obtained for Testing

\begin{tabular}{|c|c|c|c|c|}
\hline Filter Media & Manufacturer & Description & Pore Size $(\mu \mathrm{m})$ & Comments \\
\hline PMM050 & Pall & Sintered SS & 0.5 nominal & \\
\hline 0.1 TruMem & SpinTek & $\mathrm{TiO}_{2}$ on SS support & 0.1 nominal & \\
\hline SpinTek Gold & SpinTek & & 0.2 nominal & \\
\hline Sinterflo F3 & Porvair & $\begin{array}{c}\text { Sinter bonded SS } \\
\text { metal fibers }\end{array}$ & 3.0 absolute & \\
\hline SVB3-7 & ORNL & 316B support & 4 nominal & 316B- 10 $\mu \mathrm{m}$ SS \\
\hline SVB3-10 & ORNL & 316B +Atmix 5 & 1.2 nominal & Atmix5- $5 \mu \mathrm{m} \mathrm{SS}$ \\
\hline SVB3-11 & ORNL & 316B +Atmix5 & 1.2 nominal & Similar to SVB3-10 \\
\hline SVB3-12A & ORNL & $\begin{array}{c}\text { 316B +Atmix5 + } \\
\text { Atmix5-Al-titanate }\end{array}$ & 0.8 nominal & $\begin{array}{c}\text { Ceramic metal } \\
\text { composite layer }\end{array}$ \\
\hline SVB3-13 & ORNL & 316B + Atmix5 & 1.0 nominal & $41-44 \mathrm{mil}$ \\
\hline SVB3-17A & ORNL & $\begin{array}{c}\text { 316B }+ \text { Atmix5 }+ \\
\text { Atmix5-Al titanate }\end{array}$ & 1.0 nominal & $\begin{array}{l}\text { Ceramic metal } \\
\text { composite layer }\end{array}$ \\
\hline \multirow[t]{2}{*}{ SVB5-1 } & ORNL & $\begin{array}{c}\text { 316B + Atmix5 } \\
+ \text { Atmix5-Al-titanate } \\
\end{array}$ & 0.8 nominal & $\begin{array}{l}\text { Similar to SVB5-6; } \\
\text { differ in processing }\end{array}$ \\
\hline & & & Nominal & \\
\hline SVB5-6 & ORNL & $\begin{array}{c}\text { 316B + Atmix5 } \\
+ \text { Atmix5-Al-titanate }\end{array}$ & 0.8 nominal & $\begin{array}{c}\text { Differ in processing } \\
\text { vs SVB3-12A }\end{array}$ \\
\hline SVB6-1B & ORNL & 316B + Atmix3 & 0.5 nominal & $\begin{array}{l}\text { Fine porous metal } \\
\text { layers on support }\end{array}$ \\
\hline SVB6-2B & ORNL & 316B + Atmix3 & 0.5 nominal & $\begin{array}{c}\text { Atmix } 3-3 \mu \mathrm{m} \text { SS } \\
\text { same as }-1 \mathrm{~B} \text { above }\end{array}$ \\
\hline SS Support 4 & ORNL & $316 \mathrm{~B}$ & 4 nominal & Porous support \\
\hline
\end{tabular}




\subsection{Testing}

The static test cell unit (Figure 4) is a laboratory-scale filtration unit that tests flat sheet filter samples that are 4.25 inch $\mathrm{x} 3$ inch and less than 0.05 inch thick. The purpose of the static test cell is to simulate rotary microfilter operation using a small feed sample and a small filter media sample. The static test cell incorporates a flat sheet filter element in a crossflow configuration. The feed flows between the bottom plate and the filter media through a semicircular channel of 22.875 inch length and 5/16 inch diameter. The filtrate passes through the membrane and exits through the top plate (Figure 5). The total effective surface area of the filter is $0.05 \mathrm{ft}^{2}$.

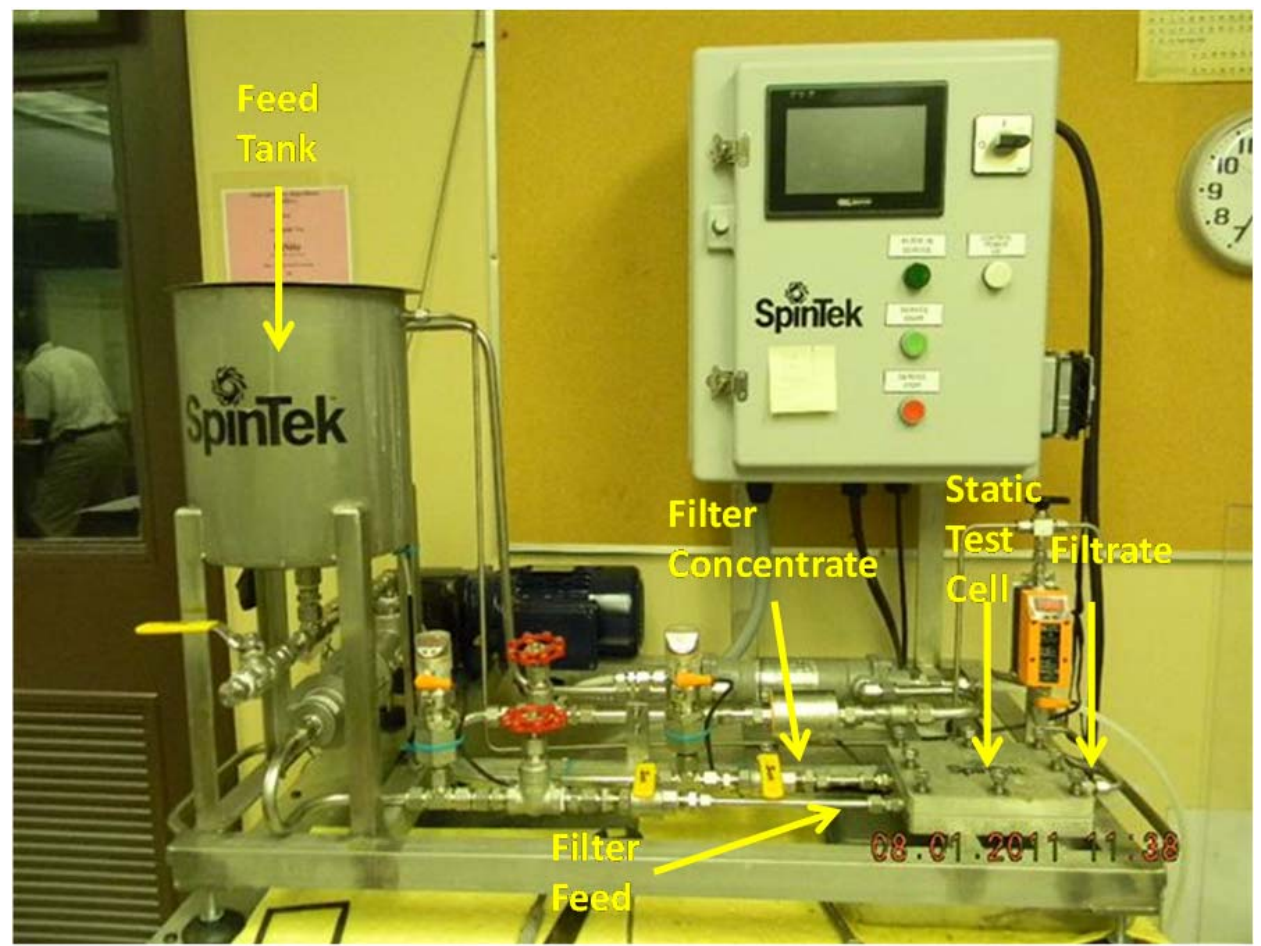

Figure 4. Static Test Cell

The static test cell consists of top and bottom plates machined from 304 stainless steel. The feed tank, skid, piping, pipe/tube fittings, and heat exchanger are all 316L stainless steel. The feed slurry is pumped from the feed tank to the static test cell. The filtrate passes through the filter membrane and exits through the top plate. The concentrate stream exits the static test cell and passes through a heat exchanger before returning to the feed tank. The filtrate can be returned to the feed tank or removed. Figure 6 shows a Process and Instrumentation Diagram (P\&ID) of the system. 


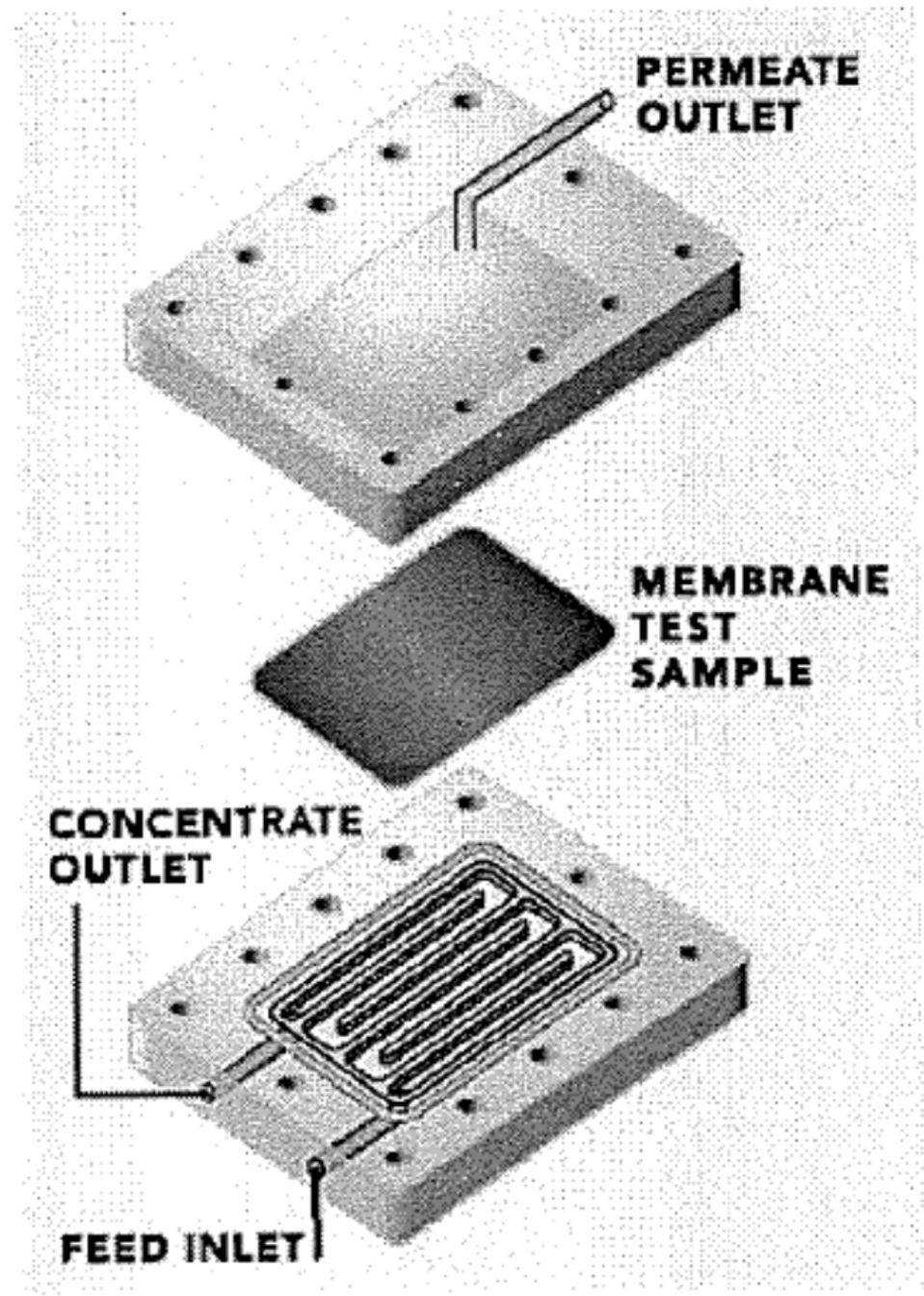

Figure 5. Filter Plate Schematic 


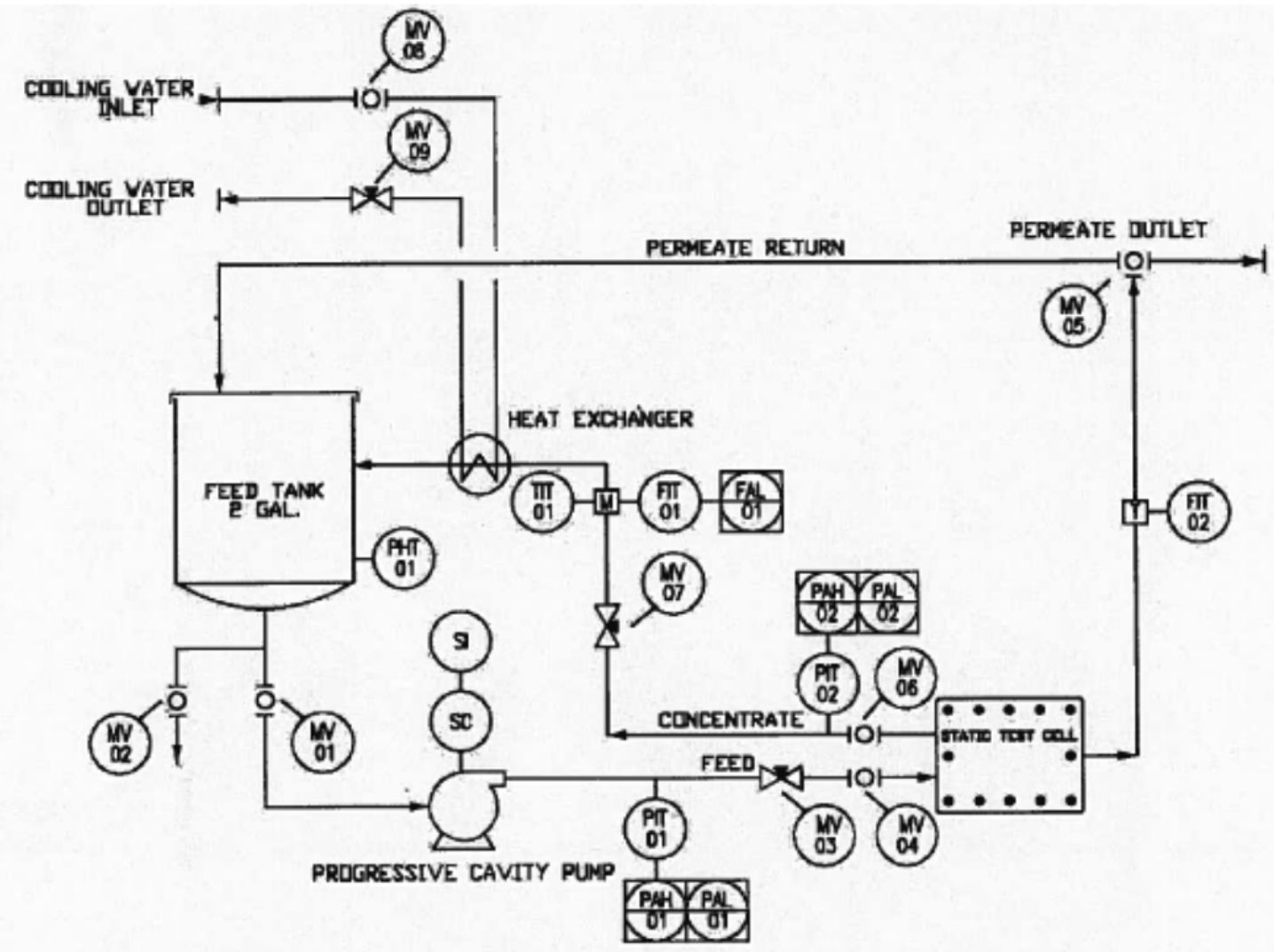

Figure 6. Static Test Cell P\&ID

SRNL prepared $4 \mathrm{~L}$ feed samples to run through the system and evaluate the filter media samples. The feed samples were deionized water, $1 \mathrm{wt} \%$ strontium carbonate in deionized water, $1 \mathrm{wt} \% \mathrm{MST}$ in simulated SRS salt solution, and $1 \mathrm{wt} \%$ simulated sludge batch 6 in simulated salt solution. Table 3 shows the composition of the salt solution. Figure 7 shows the measured particle size of the strontium carbonate, MST, and sludge. The strontium carbonate had a median particle size of $70 \mu \mathrm{m}$ (volume basis). The MST used for these experiments was selected to be representative of MST currently used at the ARP (Harrell Industries Lot\# 082709, pail 11 of 74). It had a median particle size of $16 \mu \mathrm{m}$ (volume basis). The sludge was simulated sludge batch 6 , with a median particle size of $7 \mu \mathrm{m}$ (volume basis).

Table 3. Simulated Supernate Solution Recipe (Tank 37H)

$\underline{\text { Species }}$

$\mathrm{Na}^{+}$

$\mathrm{NO}_{3}^{-}$

$\mathrm{NO}_{2}{ }^{-}$

$\mathrm{OH}^{-}$

$\mathrm{AlO}_{2}^{-}$

$\mathrm{CO}_{3}{ }^{-2}$

$\mathrm{SO}_{4}^{-2}$

$\mathrm{SiO}_{3}^{-2}$
Concentration (Molar)

6.44

2.26

0.74

2.57

0.35

0.11

0.15

$0.004^{1}$

\footnotetext{
${ }^{1}$ Based on SRS average salt solution
} 
SRNL-STI-2011-00522

Revision 0

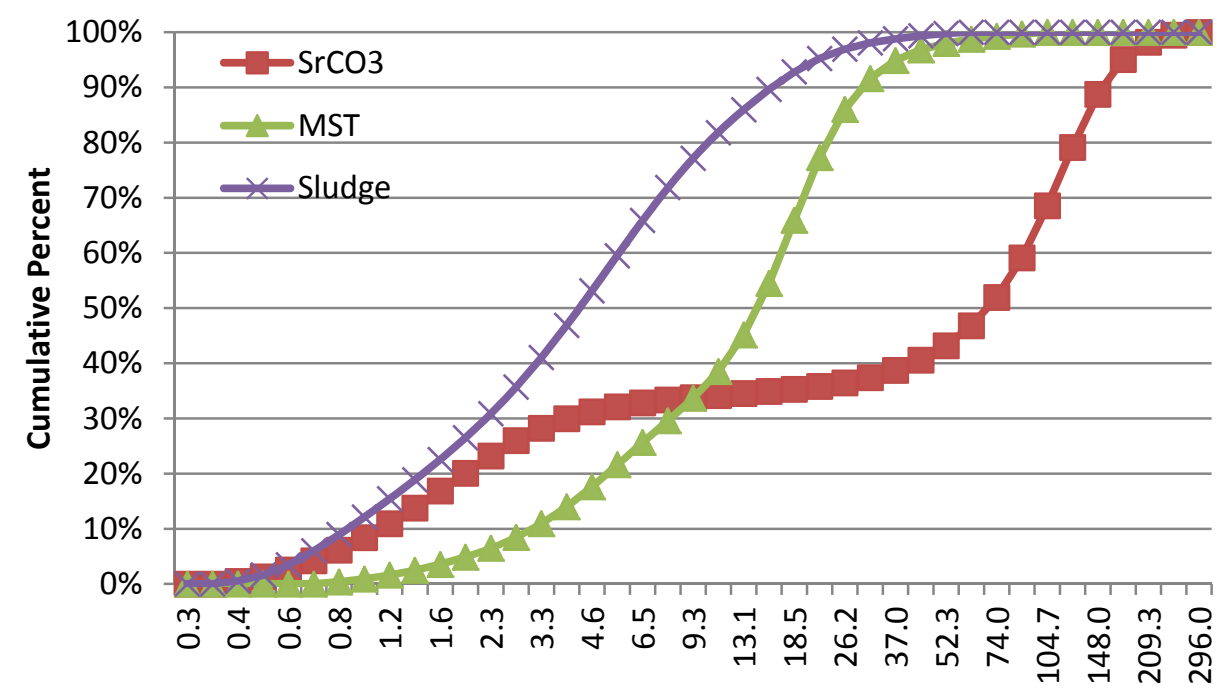

Particle Size $(\mu \mathrm{m})$

Figure 7. Particle Size Distribution of Sludge, MST, and Strontium Carbonate Particles ${ }^{2}$

In the tests with deionized water, the feed flow rate was $\sim 3 \mathrm{gpm}$, the transmembrane pressure (TMP) was 20 and $30 \mathrm{psi}$, and the temperature was $\sim 29^{\circ} \mathrm{C}$. The 3 gpm flow rate produces an axial velocity of $\sim 25$ $\mathrm{ft} / \mathrm{s}$. This velocity is higher than typical velocities used in cross flow filter tests at SRNL (10 - $14 \mathrm{ft} / \mathrm{s})$, but it is closer to the tip speed of the rotary microfilter $(60 \mathrm{ft} / \mathrm{s})$. The Reynolds number was $\sim 30,000$. Because the filtration rate of most of the membranes exceeded the maximum flow rate of the static test cell unit filtrate flow meter, these results will not be discussed in this document.

The strontium carbonate tests followed the same test conditions as the deionized water tests, except the feed flow rate was $\sim 2.5 \mathrm{gpm}$. Because the filtration rate of most of the membranes exceeded the maximum flow rate of the static test cell unit filtrate flow meter, these results will not be discussed in this document.

The tests with MST and simulated sludge slurries were performed as follows. The $1 \mathrm{wt} \%$ MST or sludge slurry was added to the feed tank. A filter membrane was installed in the static test cell. The feed pump was started, the flow rate set to $\sim 3 \mathrm{gpm}$, the feed pressure set to $30 \mathrm{psi}$, and the temperature set to $\sim 29^{\circ} \mathrm{C}$. The pressures, flow rates, and temperature were recorded every 5 minutes for 30 minutes. Personnel collected a filtrate sample every 5 minutes and visually looked for solids. The concentrate and filtrate streams were recycled to the feed tank. After 30 minutes, the feed pressure was increased to 40 psi, and the unit operated for an additional 30 minutes recording data and collecting filtrate samples every 5 minutes. The feed pump was stopped, and the filter media replaced. Following testing, the media were cleaned by rinsing with deionized water, soaking in deionized water, soaking in $2 \mathrm{M}$ nitric acid, rinsing in deionized water, soaking in $1 \mathrm{M} \mathrm{NaOH}$, and rinsing with deionized water.

\footnotetext{
${ }^{2}$ Strontium carbonate measured in water. MST and sludge measured in salt solution.
} 


\subsection{Results and Discussion}

\section{1 $\underline{\text { MST Slurries }}$}

Figure 8 shows the filter flux measured after 30 minutes with MST slurries for each of the filter media. Figure 9 shows the normalized filter flux measured after 30 minutes. The filter flux is normalized by dividing by the flux measured with the Pall PMM050 media, which is the baseline for the rotary microfilter. The Porvair filter media shows comparable, and in some cases larger flux that the PMM050 media. The ORNL SVB5-6 media shows a filter flux that is close to the PMM050. The data show a higher flux at $30 \mathrm{psi}$ than at $40 \mathrm{psi}$. One reason for this result is that the $30 \mathrm{psi}$ test was performed prior to the 40 psi test, with no cleaning or media recovery prior to performing the 40 psi test.

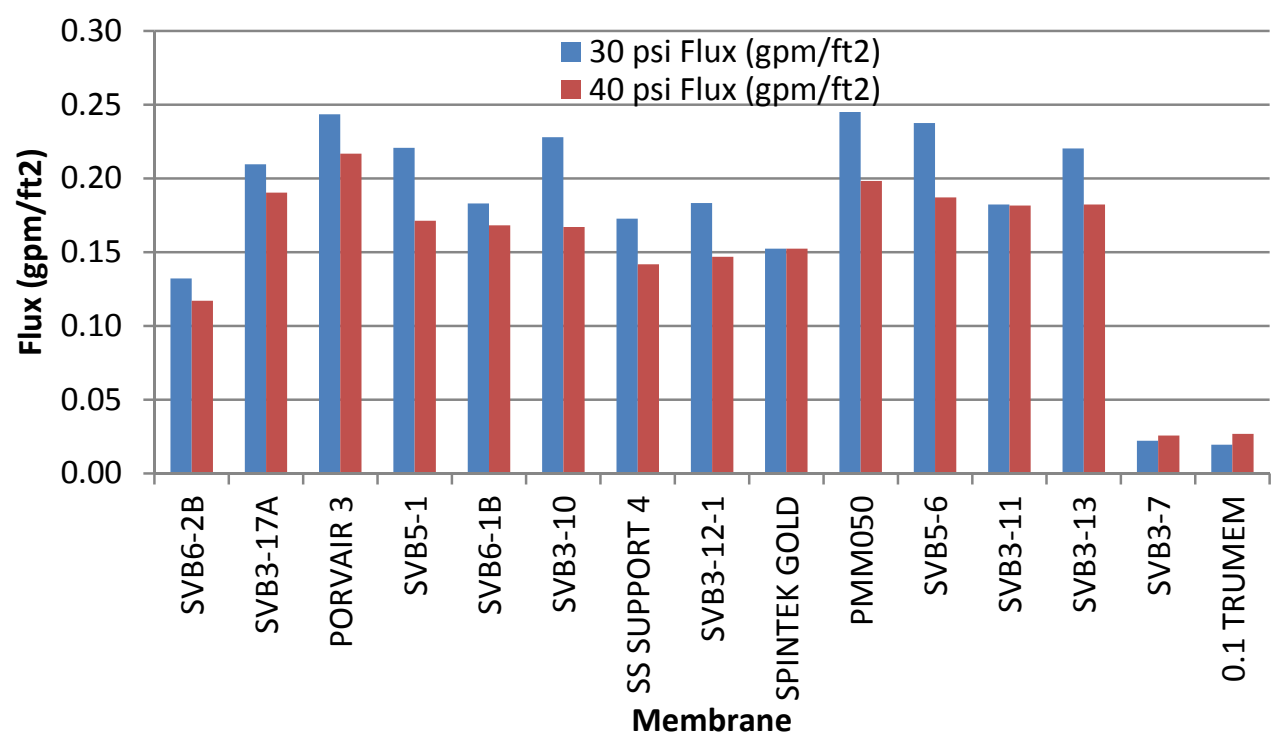

Figure 8. Filter Flux with MST Slurry

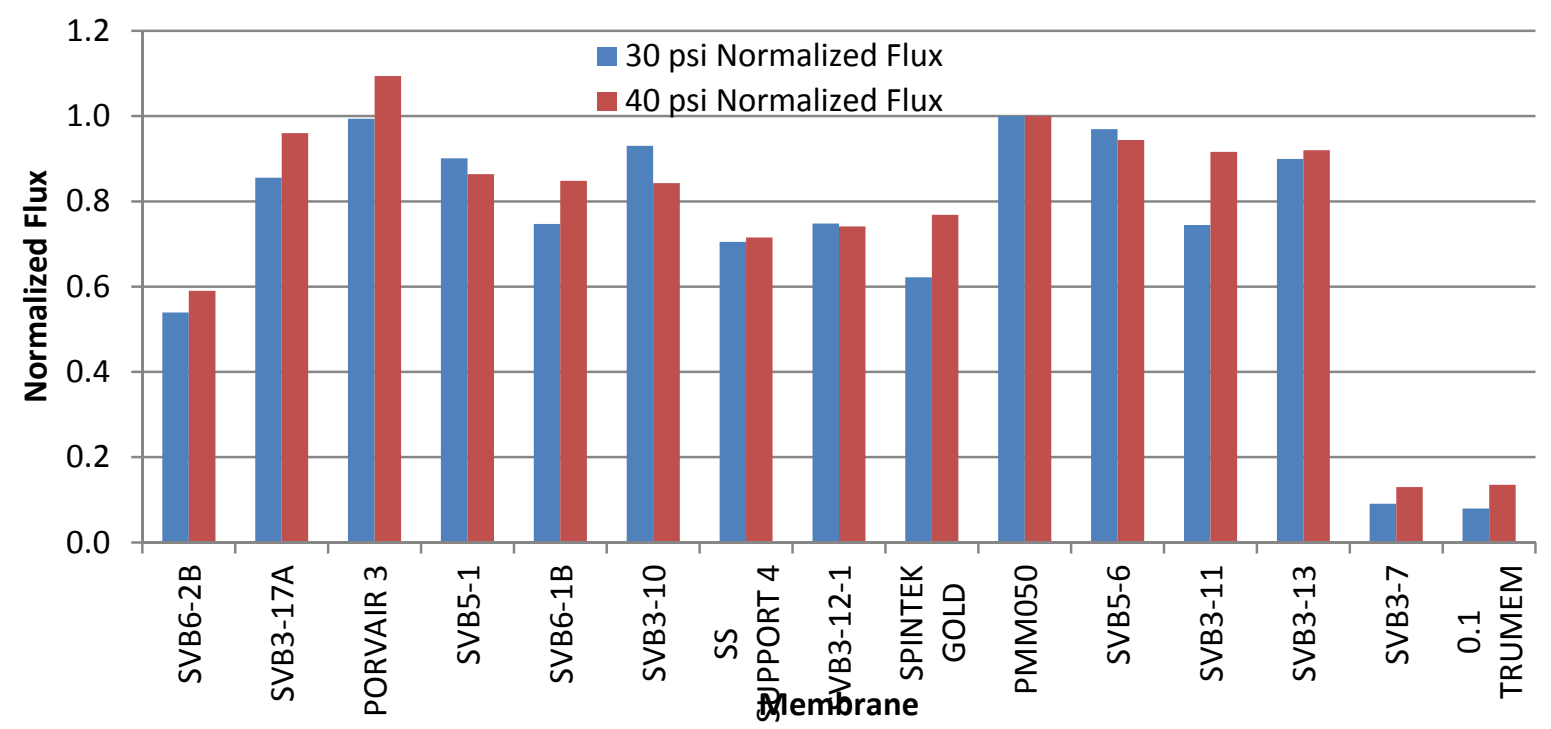

Figure 9. Normalized Filter Flux with MST Slurry 
Figure 10 and Figure 11 show the filter flux as a function of time with MST slurries at 30 psi. Figure 10 shows all of the media tested, while Figure 11 shows only the top performing media. While the PMM050 filter media produced the largest flux after 30 minutes, the Porvair, SVB5-1, SVB3-10, SVB5-6, and SVB3-13 initially produced larger flux than the PMM050, and have comparable flux after 30 minutes.

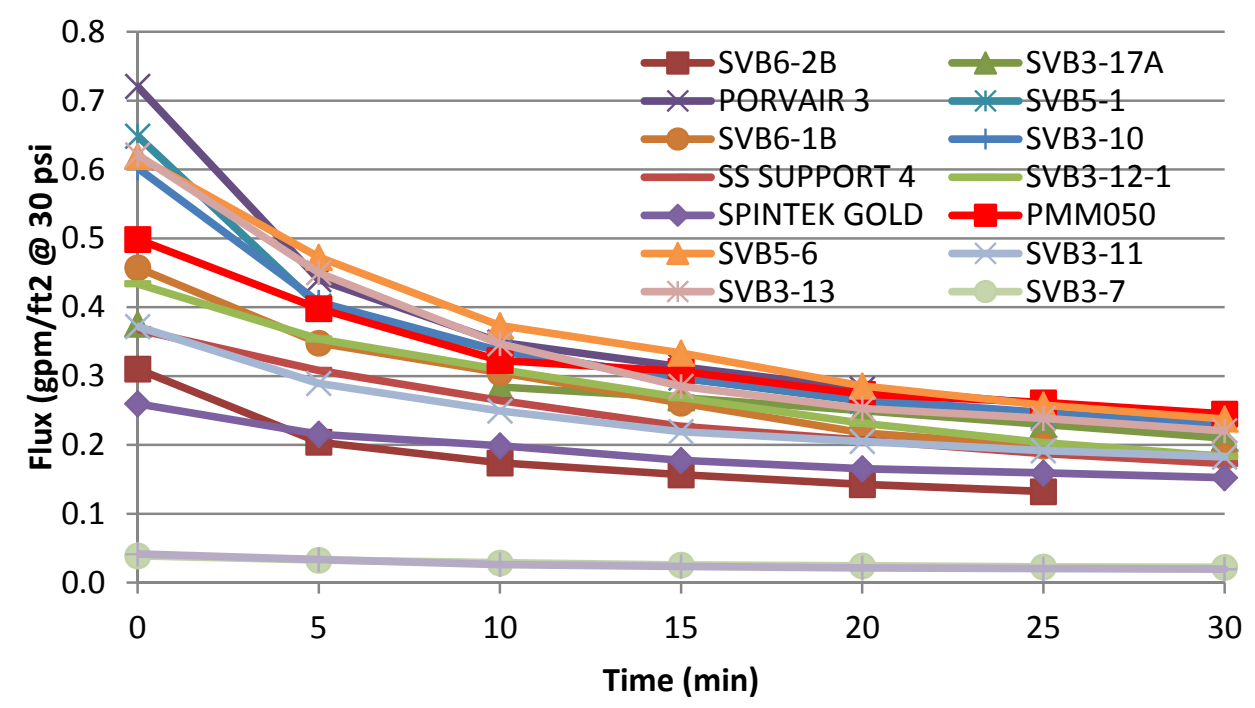

Figure 10. Filter Flux as a Function of Time with MST Slurries at 30 psi

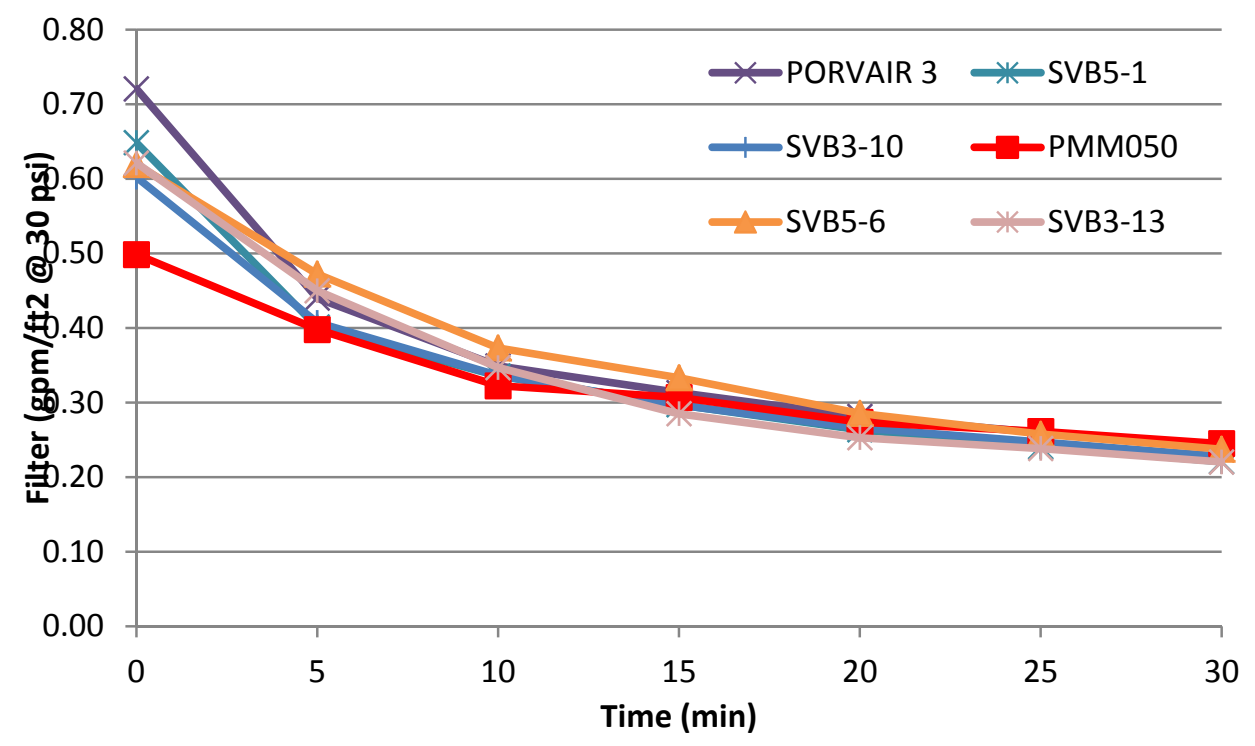

Figure 11. Filter Flux as a Function of Time with MST Slurries at 30 psi 
Figure 12 and Figure 13 show the flux as a function of time at 40 psi with MST slurries. Figure 12 shows all media tested, while Figure 13 shows only the top performing media. The Porvair media shows the largest flux. The SVB5-6 media shows comparable flux to the PMM050.

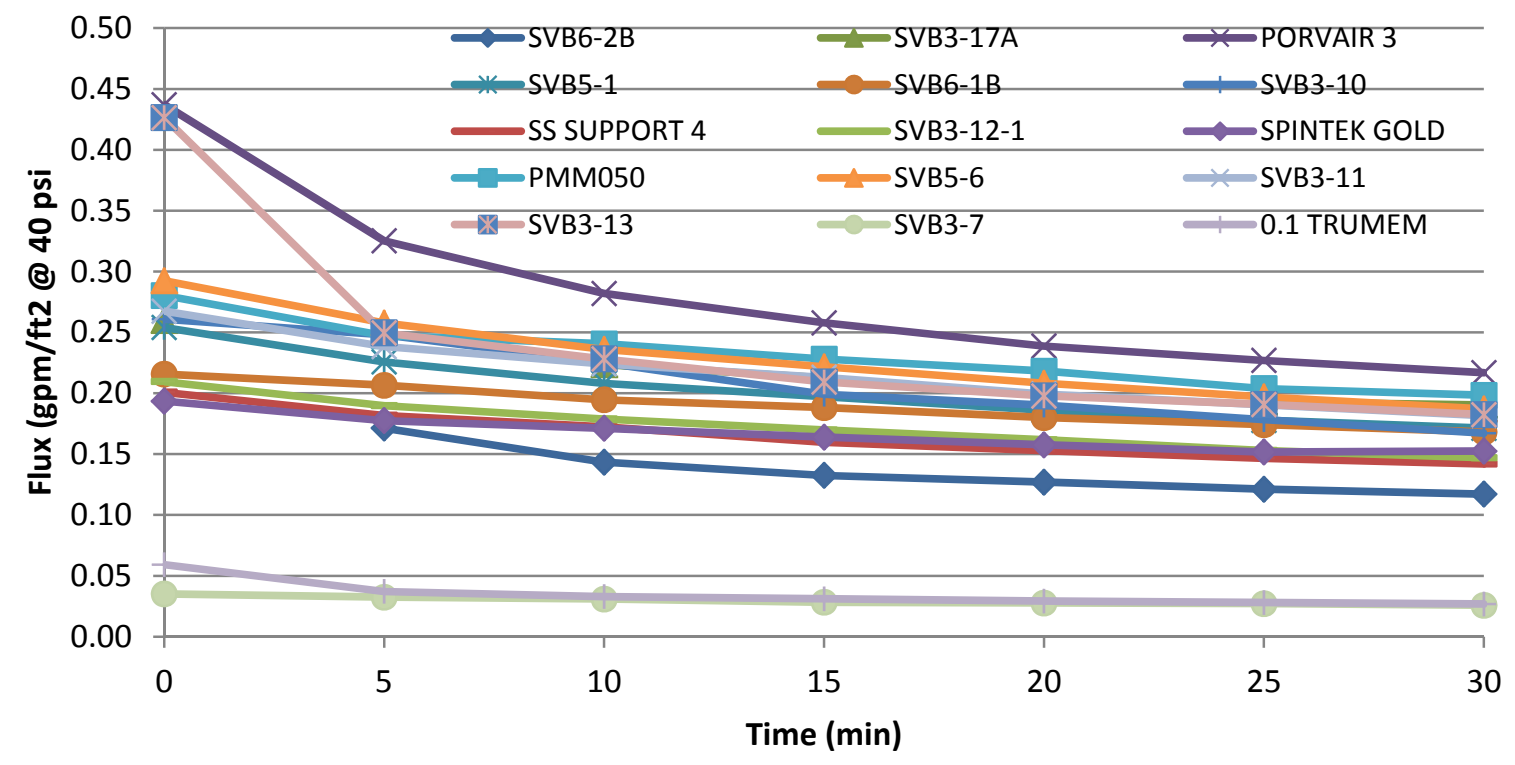

Figure 12. Filter Flux as a Function of Time with MST Slurries at 40 psi

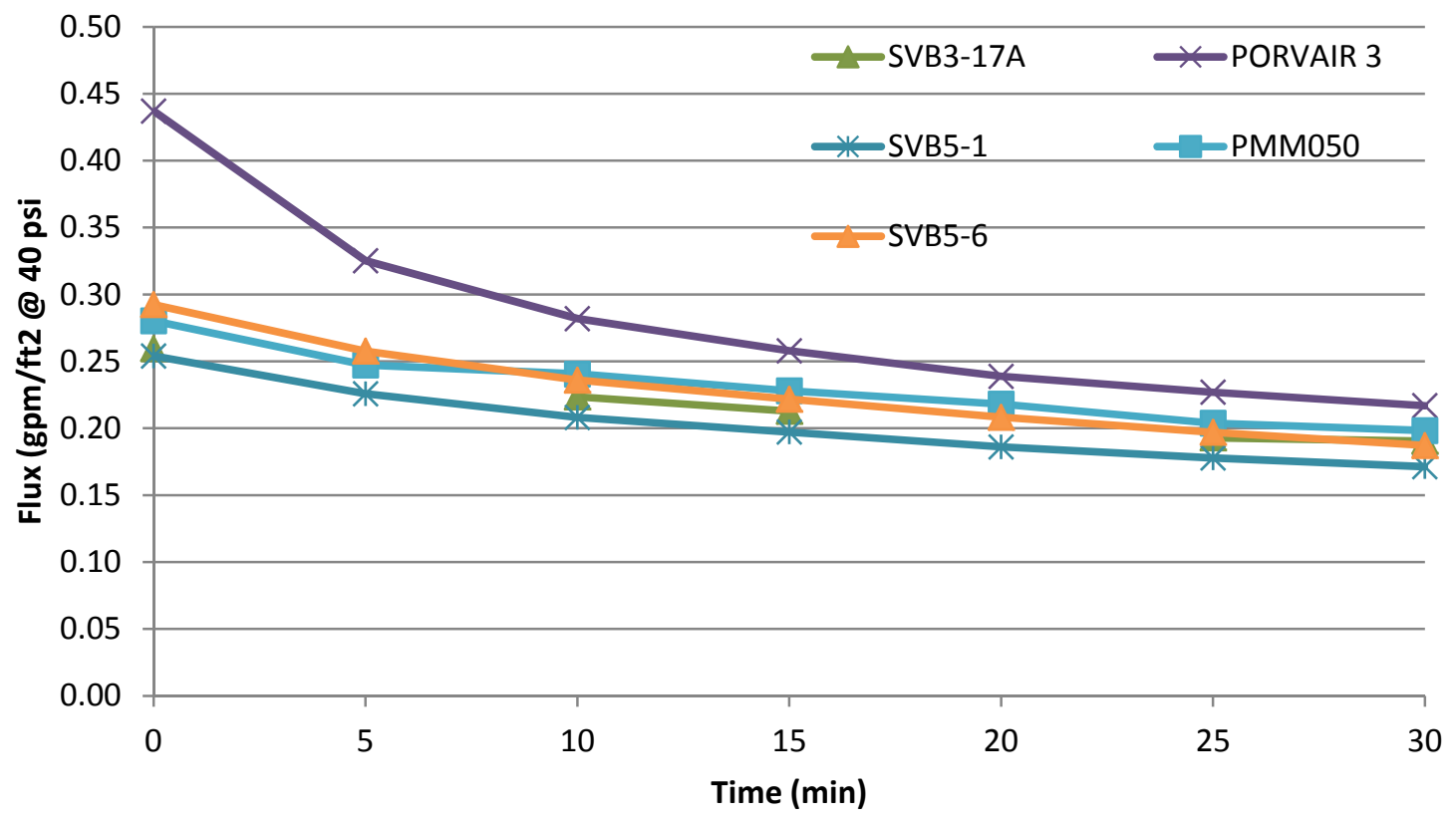

Figure 13. Filter Flux as a Function of Time with MST Slurries at 40 psi 
Figure 14 and Figure 15 show the normalized flux as a function of time for the top performing membranes.

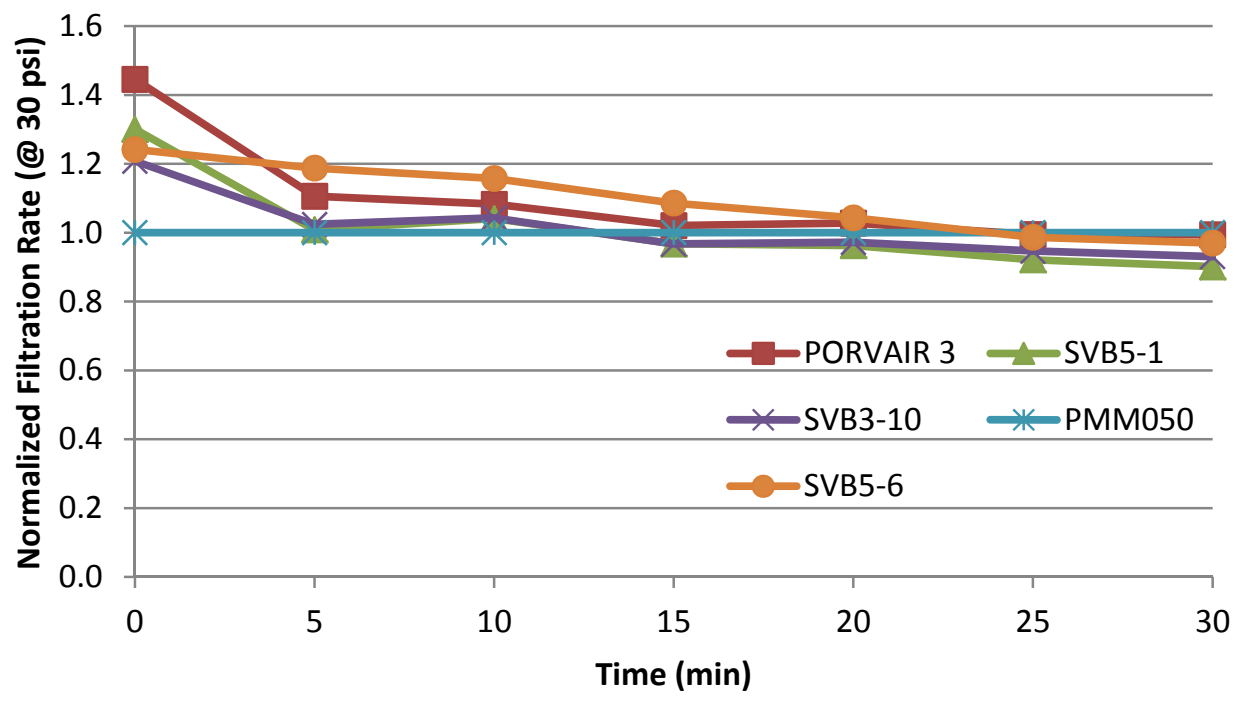

Figure 14. Normalized Filter Flux as a Function of Time with MST Slurries at 30 psi

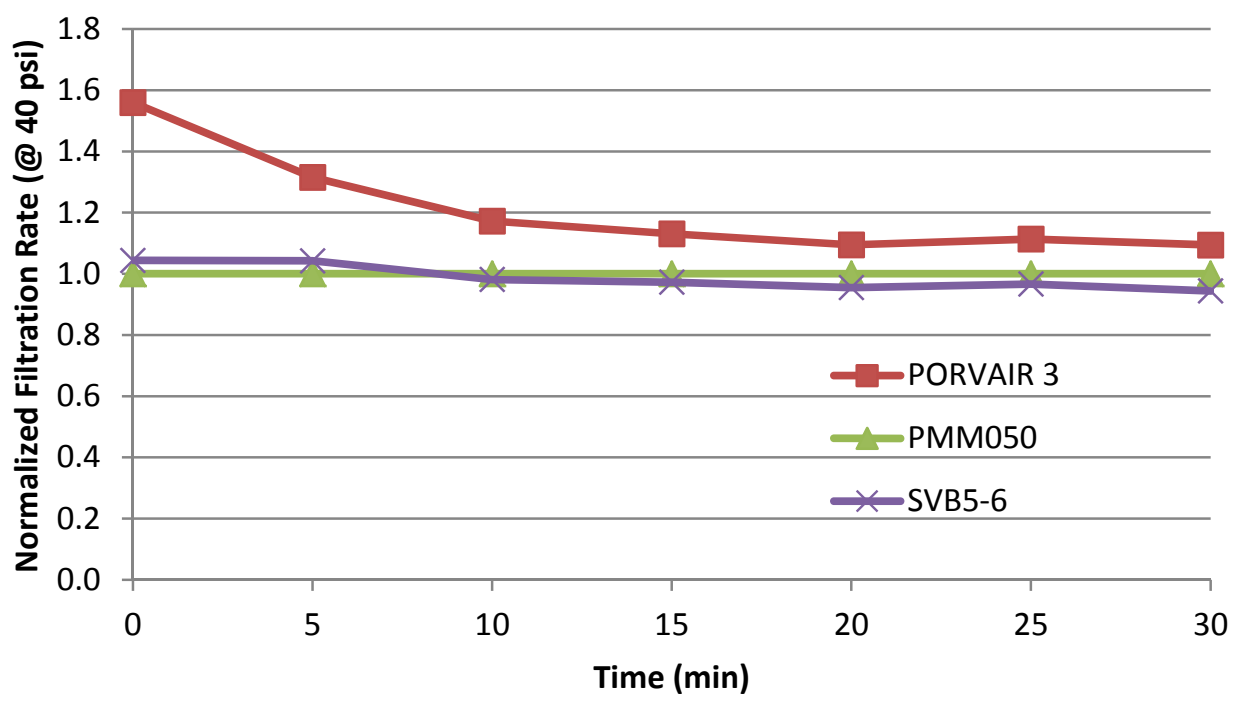

Figure 15. Normalized Filter Flux as a Function of Time with MST Slurries at 40 psi

The Porvair and the ORNL SVB5-6 filter media show the most potential to increase rotary microfilter throughput based on this test with a 1 wt \% MST in simulated salt solution feed. Personnel collected filtrate samples for visual observation every 5 minutes during testing. In all cases, the filtrate was clear indicating no passage of solids. 


\section{2 $\underline{\text { Sludge Slurries }}$}

Figure 16 and Figure 17 show the measured filter flux and measured normalized filter flux for each of the media after 30 minutes. The Porvair and ORNL SVB6-1B media show the largest filter flux, equaling or exceeding the flux produced by the Pall PMM050.

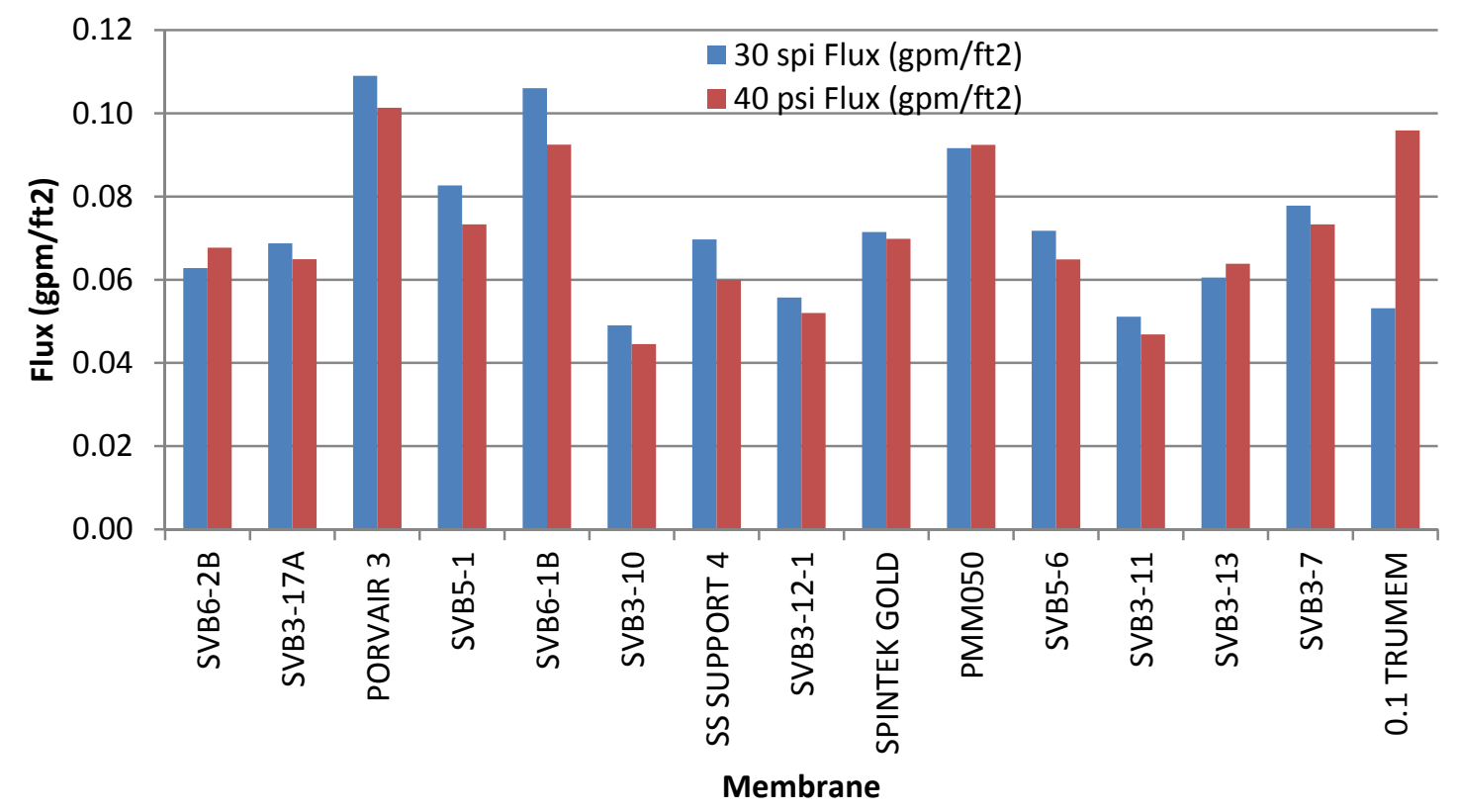

Figure 16. Filter Flux with Sludge Slurry

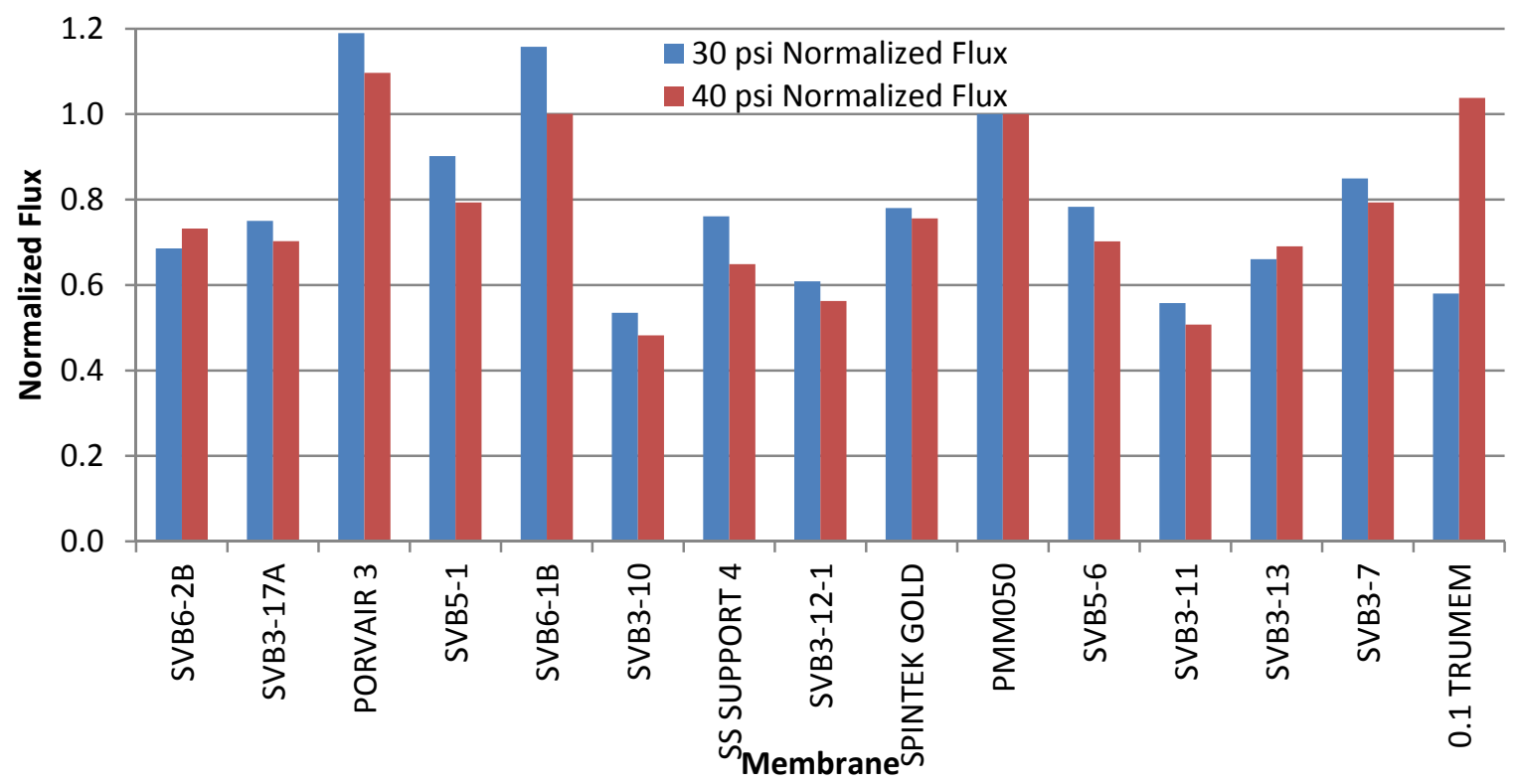

Figure 17. Normalized Filter Flux with Sludge Slurry 
Figure 18 and Figure 19 show the filter flux as a function of time with sludge slurry and a 30 psi transmembrane pressure (TMP). Figure 18 shows all media tested, while Figure 19 shows only the top performing media. The Porvair membrane produced a larger filter flux than the baseline PMM050. The ORNL SVB6-1B produced approximately the same filter flux as the PMM050. The ORNL SVB5-1 and SVB5-6 membranes produced lower flux than the PMM050.

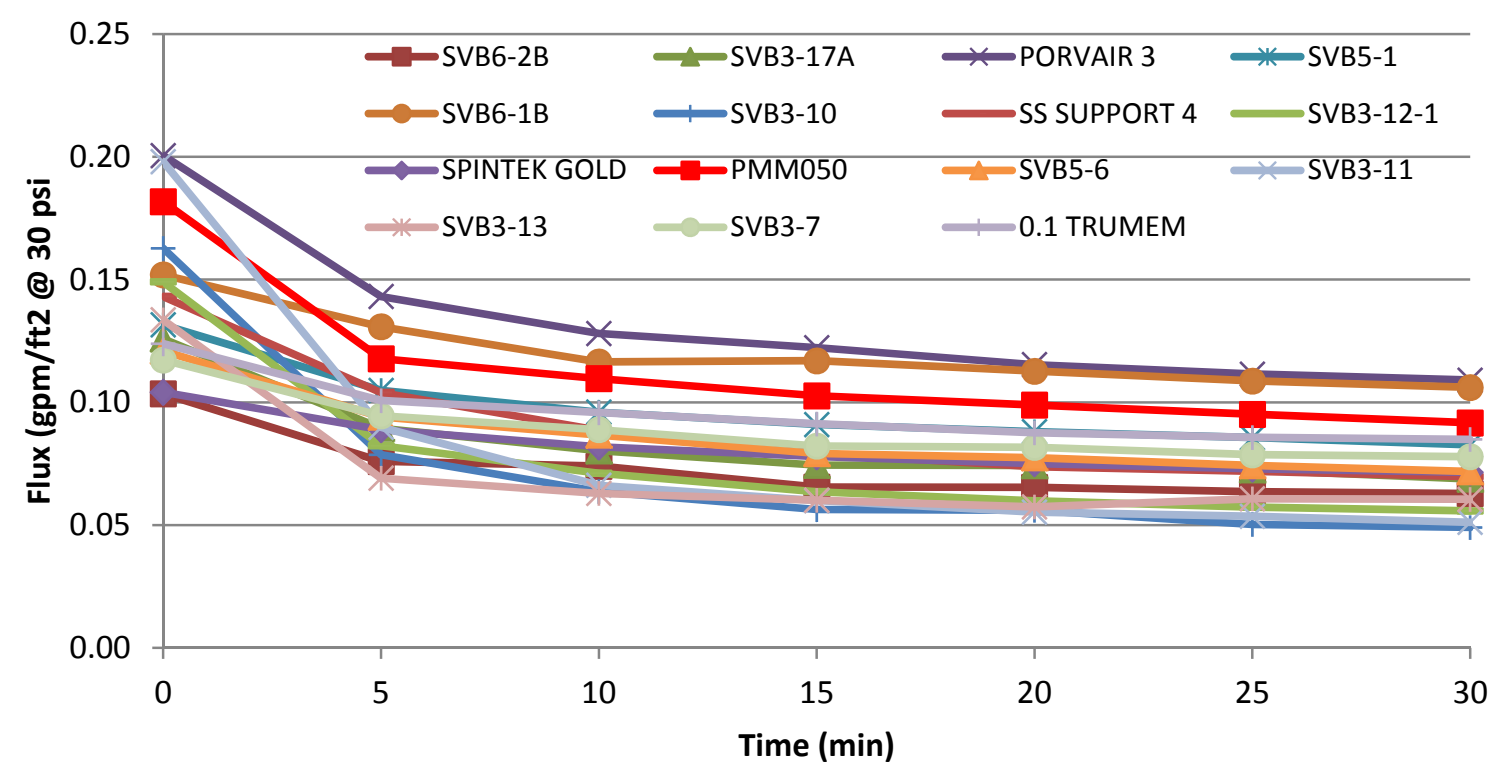

Figure 18. Filter Flux as a Function of Time with Sludge Slurry at $30 \mathrm{psi}$

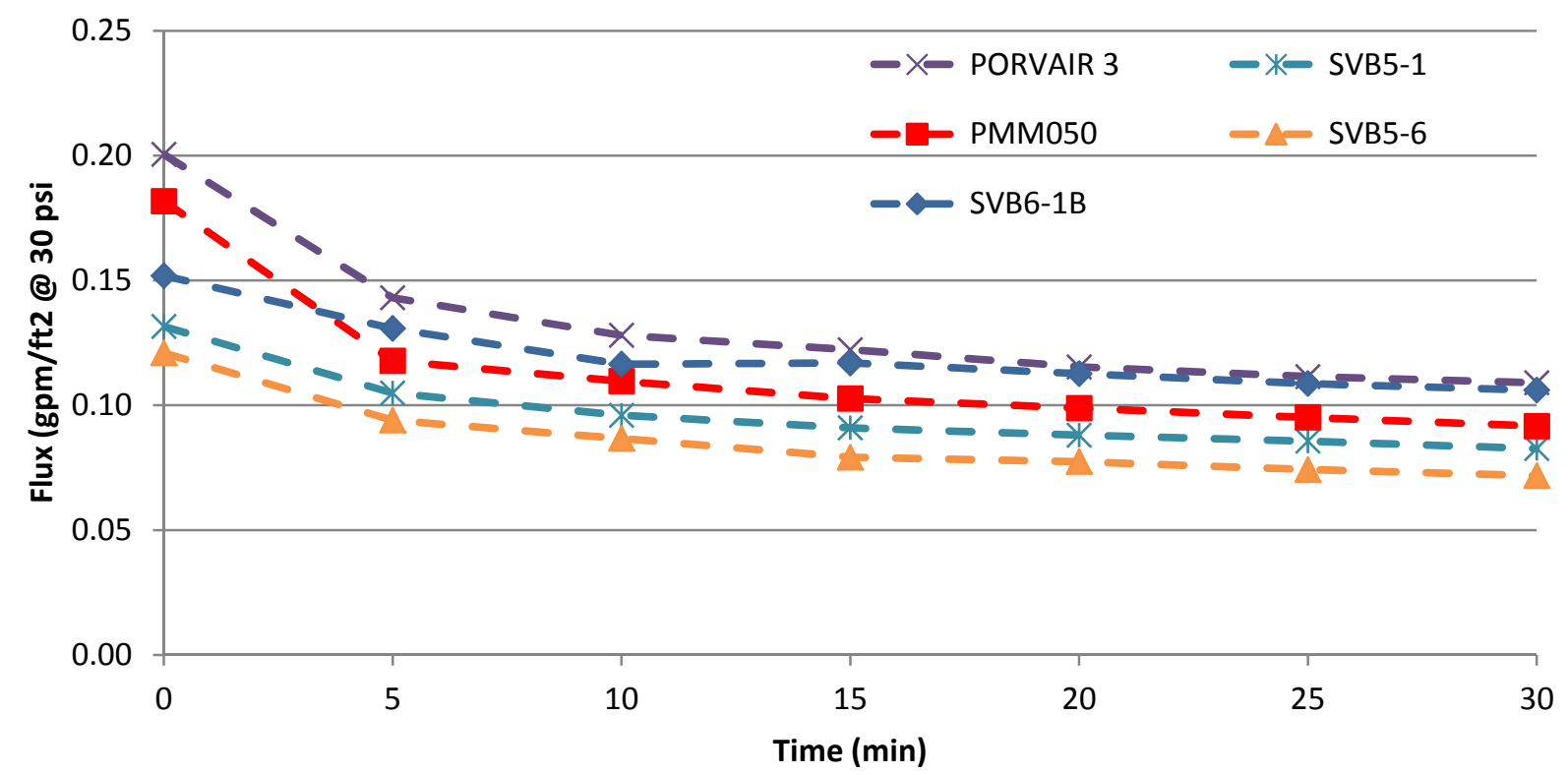

Figure 19. Filter Flux as a Function of Time with Sludge Slurry at 30 psi 
Figure 20 and Figure 21 show the filter flux as a function of time with sludge slurry and a 40 psi TMP. Figure 20 shows all media tested, while Figure 21 shows only the top performing media. The Porvair membrane produced a larger filter flux than the baseline PMM050. The ORNL SVB6-1B produced larger filter flux than the PMM050. After 30 minutes, the Trumem membrane produced larger flux than the PMM050. The ORNL SVB5-1 produced lower flux than the PMM050.

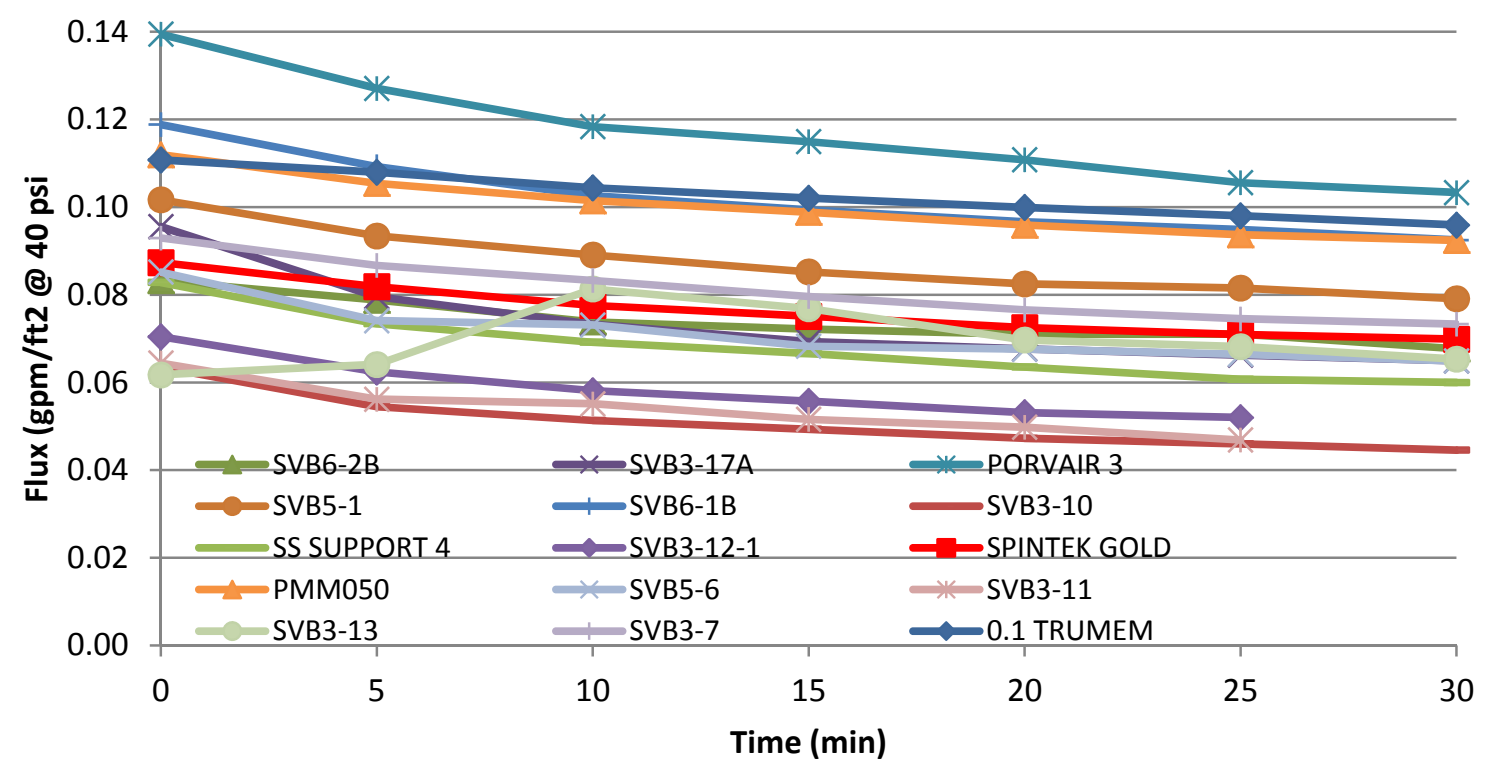

Figure 20. Filter Flux as a Function of Time with Sludge Slurry at 40 psi

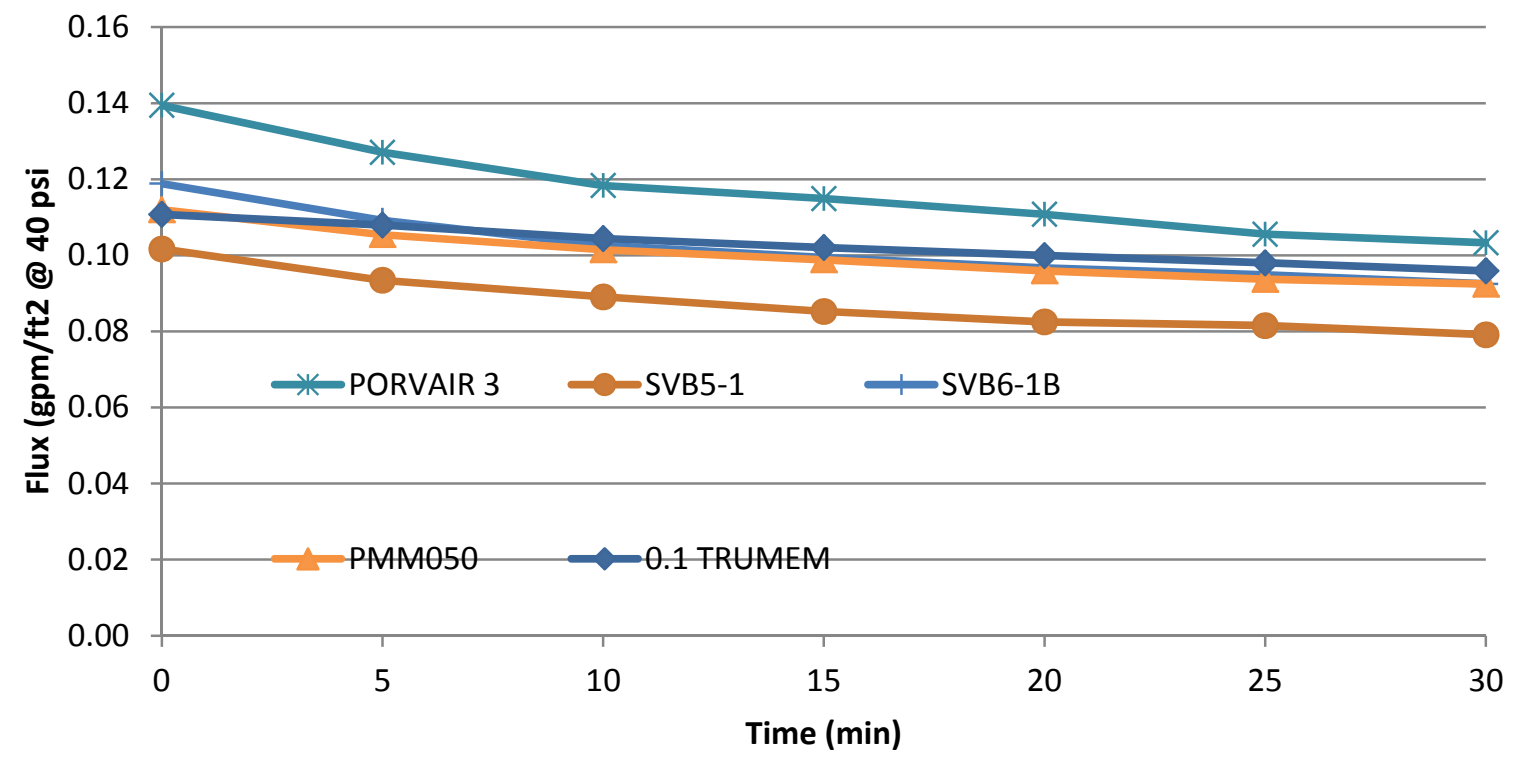

Figure 21. Filter Flux as a Function of Time with Sludge Slurry at 40 psi 
Figure 22 and Figure 23 show the normalized flux as a function of time for the top performing membranes.

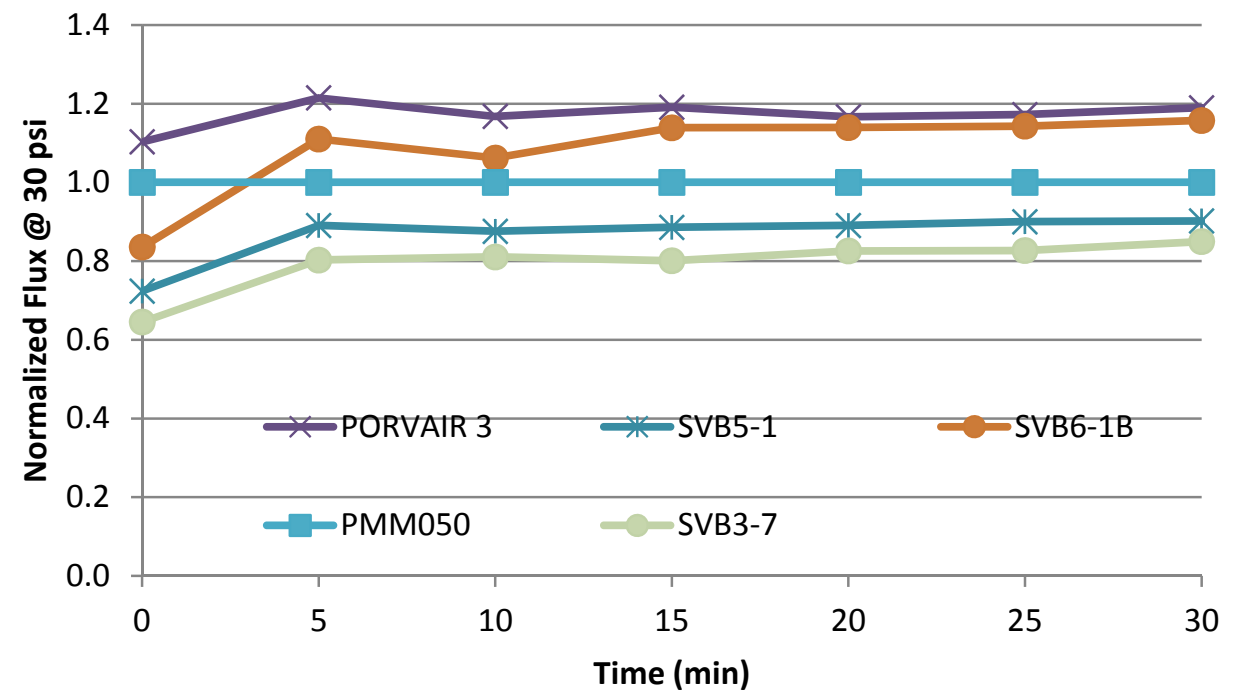

Figure 22. Normalized Filter Flux as a Function of Time with Sludge Slurry at 30 psi

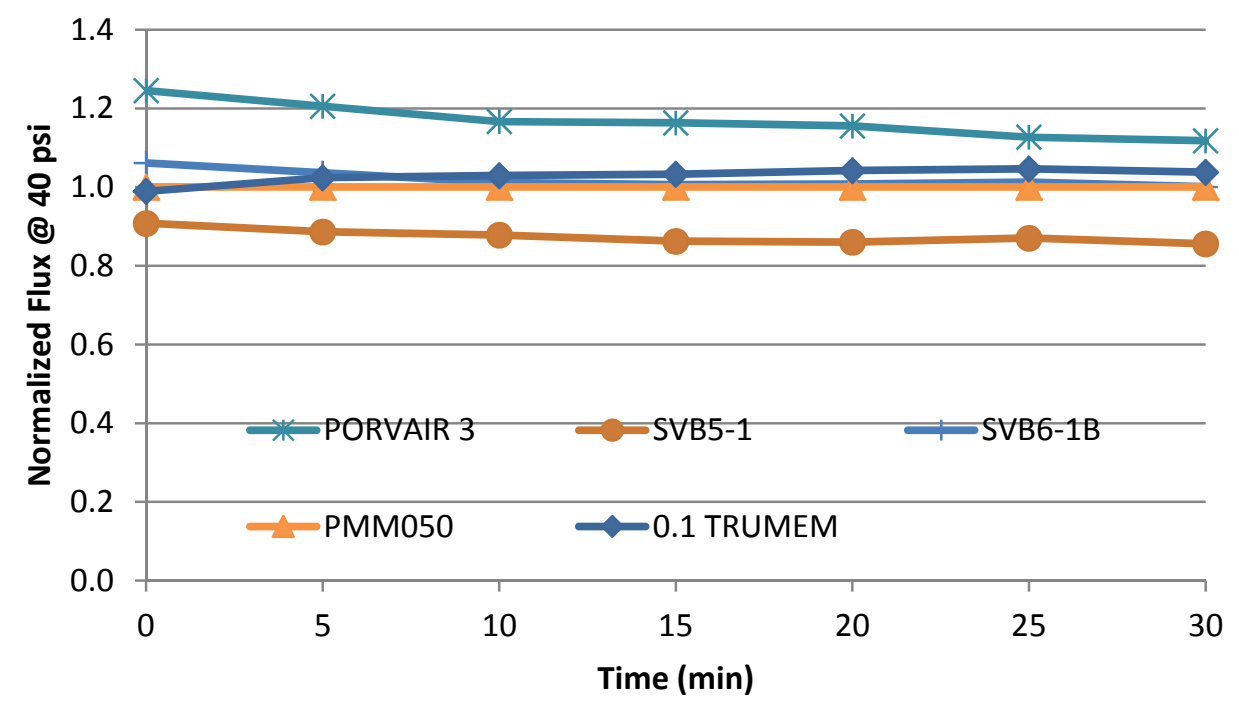

Figure 23. Normalized Filter Flux as a Function of Time with Sludge Slurry at $\mathbf{4 0}$ psi

Personnel collected filtrate samples for visual observation every 5 minutes during testing. In all cases, the filtrate was clear indicating no passage of solids.

The filter media samples produced higher filter flux with the MST slurry than with the sludge slurry. The likely cause of this difference is the difference in particle size (see Figure 7). The sludge had a smaller median particle size ( $7 \mu \mathrm{m}$ versus $16 \mu \mathrm{m}$ ) and a larger fraction of submicron particles (12\% versus $1 \%$ ). 
The Porvair and the ORNL SVB6-1B filter media show the most potential to increase rotary microfilter throughput based on this test with a $1 \mathrm{wt} \%$ simulated sludge in simulated salt solution feed.

The ORNL $0.5 \mu \mathrm{m}$ SVB6-1B membrane produced the same or higher flux than the PMM050 membrane with simulated sludge feeds. SVB6-1B is a composite membrane with several layers of thin uniform fine particle layers. Given the number of fine $(<1 \mu \mathrm{m})$ particles, this type of membrane has the potential to offer better long term performance than a symmetric membrane with a larger pore size.

In comparing the pore size of the PMM050, the Porvair Sinterflo 3, and the ORNL SVB6-1B, the stated pore sizes were measured by different organization and by different processes. The PMM pore size is based on the removal of particles of a given size. The PMM050 removed $90 \%$ of particles larger than 0.6 $\mu \mathrm{m}, 99 \%$ of particles larger than $2 \mu \mathrm{m}, 99.9 \%$ of the particles larger than $4 \mu \mathrm{m}$, and $100 \%$ of the particles larger than $5 \mu \mathrm{m}$. The Porvair pore size is based on the removal of particles of a given size. The Porvair Sinterflo 3 removed $99.53 \%$ of the particles larger than $0.3 \mu \mathrm{m}, 99.98 \%$ of the particles larger than 0.5 $\mu \mathrm{m}$, and $99.9 \%$ of the particles larger than $5 \mu \mathrm{m}$. The ORNL pore size is determined by measuring the percentage of flow that passes through pores of different size. The SVB6-1B showed a minimum pore size of $0.35 \mu \mathrm{m}$ and a maximum pore size of $0.9 \mu \mathrm{m}$.

\subsection{Conclusions}

- The Porvair Sinterflo 3 filter media produced 15-20\% higher flux than the baseline Pall PMM050 membrane.

- The ORNL SVB6-1B membrane produced the same and up to $20 \%$ higher flux than the Pall PMM050 membrane and comparable flux to the Porvair membrane with simulated sludge feeds.

\subsection{Recommendations}

- Because of the limited testing and the small difference in filter flux between the PMM050, Porvair Sinterflo 3, and the ORNL SVB6-1B, the authors recommend additional bench-scale testing be performed to select the best filter media prior to fabricating and testing full-scale filter disks.

- This testing would include longer run times, multiple filtering and cleaning cycles, and additional solids loadings. Additionally, these tests would include measuring turbidity rather than visual observations to assess filtrate quality. 
SRNL-STI-2011-00522

Revision 0

\subsection{References}

${ }^{1}$ M. R. Poirier, "Filtration Systems, Inc., Report for SRS SpinTek Rotary Microfilter”, WSRC-TR-200100214, Rev. 1, May 4, 2001.

${ }^{2}$ Michael R. Poirier, David T. Herman, Samuel D. Fink, Ralph Haggard, Travis Deal, Carol Stork, and Vincent Van Brunt, "Pilot-Scale Testing of a SpinTek Rotary Microfilter with SRS Simulated High Level Waste”, WSRC-TR-2003-00071, February 3, 2003.

${ }^{3}$ D. T. Herman, M. R. Poirier, D. T. Hobbs, S. D. Fink, "Testing of the SpinTek Rotary Microfilter Using Actual Waste”, WSRC-TR-2003-00030, February 2003.

${ }^{4}$ D. T. Herman, M. R. Poirier, and S. D. Fink, "Testing and Evaluation of the Modified Design of the 25Disk Rotary Microfilter”, WSRC-STI-2006-00073, August 2006.

${ }^{5}$ M. R. Poirier, D. T. Herman, D. B. Stefanko, "Testing of a Rotary Microfilter to Support Hanford Applications”, WSRC-STI-2008-00339, June 26, 2008.

${ }^{6}$ N. R. Mann, R. S. Herbst, T. G. Garn, M. R. Poirier, and S. D. Fink, "Alternative Ultrafiltration Membrane Testing for the SRS Baseline Process”, INEEL/EXT-04-01933, June 2004.

${ }^{7}$ M. R. Poirier, D. T. Herman, and S. D. Fink, "Rotary Microfilter Media Evaluation”, WSRC-TR-200500205, April 20, 2005.

${ }^{8}$ M. R. Poirier, F. F. Fondeur, D. P. Lambert, David T. Hobbs, and S. D. Fink, "Particle Size of Simulated SRS Sludge, Actual SRS Sludge, and Monosodium Titanate”, WSRC-TR-2003-00221, May 20, 2003. 


\section{Distribution:}
A. B. Barnes, 999-W
D. A. Crowley, 773-43A
A. P. Fellinger, 773-42A
S. D. Fink, 773-A
B. J. Giddings, 786-5A
C. C. Herman, 999-W
S. L. Marra, 773-A
A. M. Murray, 773-A
F. M. Pennebaker, 773-42A
W. R. Wilmarth, 773-A
P. R. Jackson, DOE-SR, 703-46A
K. H. Subramanian, 766-H
M. R. Poirier, 773-42A
D. T. Herman, 735-11A
C. A. Nash, 773-42A
R. Bhave, ORNL 